\title{
Rheological Behavior and Strength Characteristics of Cement Paste and Mortar with Fly Ash and GGBS Admixtures
}

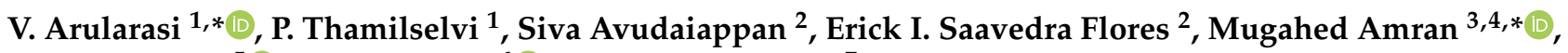 \\ Roman Fediuk $^{5}$, Nikolai Vatin ${ }^{6}$ (D) and Maria Karelina ${ }^{7}$ \\ 1 Department of Civil Engineering, College of Engineering Guindy, Anna University, Chennai 600025, India; \\ drselvi08@gmail.com \\ 2 Departamento de Ingeniería en Obras Civiles, Universidad de Santiago de Chile, Av. Ecuador 3659, Estación Central, \\ Santiago 3659, Chile; siva.avudaiappan@usach.cl (S.A.); erick.saavedra@usach.cl (E.I.S.F.) \\ 3 Department of Civil Engineering, College of Engineering, Prince Sattam Bin Abdulaziz University, \\ Alkharj 11942, Saudi Arabia \\ 4 Department of Civil Engineering, Faculty of Engineering and IT, Amran University, Amran 9677, Yemen \\ 5 Polytechnic Institute, Far Eastern Federal University, 690922 Vladivostok, Russia; fedyuk.rs@dvfu.ru \\ 6 Peter the Great St. Petersburg Polytechnic University, 195251 St. Petersburg, Russia; vatin@mail.ru \\ 7 Moscow Automobile and Road Construction University, 125319 Moscow, Russia; karelinamu@mail.ru \\ * Correspondence: varularasi@gmail.com (V.A.); m.amran@psau.edu.sa (M.A.)
}

Citation: Arularasi, V.; Thamilselvi, P.; Avudaiappan, S.; Saavedra Flores, E.I.; Amran, M.; Fediuk, R.; Vatin, N.; Karelina, M. Rheological Behavior and Strength Characteristics of Cement Paste and Mortar with Fly Ash and GGBS Admixtures. Sustainability 2021, 13, 9600. https:// doi.org/10.3390/su13179600

Academic Editors: Kequan Yu, Shuguang Liu, Guangcheng Long, Wenjun Zhu, Lili Kan, Yao Ding, Yan Xiong and Václav Nežerka

Received: 21 May 2021

Accepted: 25 June 2021

Published: 26 August 2021

Publisher's Note: MDPI stays neutral with regard to jurisdictional claims in published maps and institutional affiliations.

Copyright: () 2021 by the authors. Licensee MDPI, Basel, Switzerland. This article is an open access article distributed under the terms and conditions of the Creative Commons Attribution (CC BY) license (https:// creativecommons.org/licenses/by/ $4.0 /)$.

\begin{abstract}
A cement paste or mortar is composed of a mineral skeleton with micron to millimetersized grains, surrounded by water filaments. The cohesion or shear resistance in the cement paste and mortar is caused by capillary forces of action. In the case of mortar mixes, there is friction between the particles. Therefore, the mortar mixture shows both friction between particles and cohesion, while the paste shows only cohesion, and the friction between particles is negligible. The property of the cement paste is greatly influenced by the rheological characteristics like cohesion and internal angle friction. It is also interesting that when studying the rheology of fresh concrete, the rheological behavior of cement paste and mortar has direct applicability. In this paper, the rheological characteristics of cement paste and mortar with and without mineral admixtures, that is, fly ash and ground granulated blast-furnace slag (GGBS), were studied. A cement mortar mix with a cement-to-sand ratio of 1:3 was investigated, including fly ash replacement from $10 \%$ to $40 \%$, and GGBS from $10 \%$ to $70 \%$ of the weight of the cement. A suitable blend of fly ash, GGBS, and ordinary Portland cement (OPC) was also selected to determine rheological parameters. For mortar mixtures, the flow table was conducted for workability studies. The flexural and split tensile strength tests were conducted on various mortar mixtures for different curing times. The results indicate that in the presence of a mineral mixture of fly ash and GGBS, the rheological behavior of paste and mortar is similar. Compared with OPC-GGBS-based mixtures, both cement with fly ash and ternary mixtures show less shear resistance or impact resistance. The rheological behavior of the mortar also matches the rheological behavior in the flow table test. Therefore, it is easy to use the vane shear test equipment to conduct cohesion studies to understand the properties of cement paste and mortar using mineral admixtures. The strength results show that the long-term strength of GGBS-based mixtures and ternary mixed mixtures is better than that of fly-ash-based mixtures. For all mixtures, the strength characteristics are greatest at a $\mathrm{w} / \mathrm{b}$ ratio of 0.6 .
\end{abstract}

Keywords: rheology; fly ash; GGBS; vane shear; cohesion; ternary blend

\section{Introduction}

Concrete is an extraordinary composite material, widely used in the construction industry. It consists of a mix of fine and coarse aggregates bonded together with cement paste [1,2]. Evaluating the performance of cement is a very challenging task because it changes significantly when it comes into contact with water [3]. The addition of different 
new materials to cement increases the task of evaluating chemical reactions and physical changes occurring inside the cement slurry. Some problems encountered by cement slurries are: (i) cement particles exhibit inter-particle interaction and have electrostatic repulsion, (ii) thixotropic behavior, (iii) chemical reaction with respect to time, and (iv) temperature effects, among others [4-7]. The addition of admixtures increases temperature during the mixing of concrete, greatly reducing the diameter spread [8]. Furthermore, due to the thixotropic behavior, yield stress changes over time. In general, the measurement of rheological parameters shows the challenges of the equipment needed and test procedures involved in the experiments $[9,10]$. The slump cone test is the common workability test figured by Abrams and used by Chapman in the U.S.A in 1910 [11-13]. Graf from Germany invented the flow table test in 1933 [14]. These experimental tests provided a single value for the flow parameter. Later, Tattersall $[15,16]$ fabricated a rheometer that gives two parameters, such as yield stress and plastic viscosity, to perform an elaborate study on the flow characteristics of cement paste and mortar, and also for concrete. It is said that cementbased materials are regarded as Bingham fluids. Hattori-Izumi's theory proves that cementbased materials exhibit thixotropic characteristics. Wallevik conducted rheological tests using different rheometers [17]. Extensive research has been carried out to understand the effects of lignosulfonate, thixotropy, and particle migration [18-21]. In the rheological study, viscosity plays a major role, which has a direct impact on the hardened concrete [22-24]. Viscosity directly affects the flowability of the concrete in the fresh state and the strength in the hardened state. In particular, rheology controls the yield value and plastic viscosity [25]. The yield value is divided into static and dynamic values [22,26,27]. The yield value is related to the stress required for the material to start displaying the flow characteristics. The dynamic yield value is regarded as a factor responsible for making the flowing material enter into a static state [22,28]. The rheological characteristics of cement paste and mortar measured using a vane shear instrument, which is easily available in laboratories, are focused on in this article.

The rheology, or flow, of any particle is an important phase, and it has to be deeply studied in order to enhance the properties of the particle [29]. In cement paste and mortar, rheology has not been concentrated on as compared to the importance given to the strength properties. Studying the rheology of concrete is not commonly carried out by researchers since the cost involved in conducting the research is very high, and there has been a lag in the study of the rheology of concrete [30]. The invention of self-compacting concrete, however, has led researchers to think about the flow characteristics [31]. In the current circumstance, self-compacting concrete is unavoidable in the construction industry [32-35]. Various mineral admixtures are added to the concrete to make it self-compacting. The flow of the concrete is impacted by various properties of the ingredients added, such as size, shape, texture, water absorption capacity, cohesion, and inter-particle attraction [36]. The composite material indicates different flow behavior when different ratios of the materials are added. There are several combinations of ingredients from which self-compacting concrete can be prepared. Conducting a rheological study for all the combinations of the concrete is a time-consuming and tedious process. It is likely difficult for a researcher to conclude that a particular combination of the concrete ingredients will give better flow, because the rheology of the concrete changes over time. The yield value measured for one particular instant will exhibit different values with respect to the next time period.

In the plastic type of shear-related behavior, the material will start its flow only when the shear stress crosses its critical value $\tau_{0}=C+\sigma \tan \varphi$, where $C$ is cohesion, $\varphi$ is the coefficient of internal friction, and $\tau_{0}$ is yield stress. The existence of yield stress is due to the inherent force acting on the mixed particles, which can be measured by the cohesive force ' $C$ ' caused by the friction between individual particles $[37,38]$. From this equation, by using geotechnical equipment under static conditions, the inherent forces likes cohesion and friction occur due to the abrasion of particles. The formula used to measure the cohesive force is given by Equation (1).

$$
\mathrm{C}=\mathrm{T} / \pi \mathrm{D}^{2}(\mathrm{H} / 2+\mathrm{D} / 6)
$$


where $\mathrm{D}$ and $\mathrm{H}$ are the constants of the blades used.

It is stated that the addition of fly ash and GGBS with cement decreases yield stress and plastic viscosity [35,39-42]. A standard reference material to improve the flow characteristics of the cementing material has also been developed. The substitution of lime powder and glycerol for cement and water satisfies the flow of the matrix [43]. Feys et al. [44] compared the results of the rheological parameter obtained from a rheometer and standard workability test. In the end, they came to the conclusion that the standard procedure does not work for all rheometers, and comparing the resulting values will not provide a clear understanding, unless the geometry of the equipment is similar [44]. A different mortar phase of SCC has also been developed, in which waste glass powder was used as the replacement material [45]. It was concluded that increasing addition of the glass powder decreased the relative yield stress and relative plastic viscosity, and that the best model to analyze the rheological parameter is the Herschel and Bulkley model. Kong stated that temperature and time reduce the mortar phase fluidity [8]. A temperature between 0 to 60 degrees reduces the mortar spread diameter in a linear fashion with an increase in time. At different temperatures, the yield stress increases in a linear fashion. Kwan et al. concentrated on water film thickness (WFT) and paste film thickness of the cementing material and its impact on rheology. The conclusion reached was that the adhesiveness of the mortar depends mainly on WFT, and PFT has a very minimal effect. Another conclusion reached was that the water/cement ratio and cement/aggregate ratio have major effects on the cohesion, adhesiveness, and rheology of the mortar [46]. Haist and Ferrara investigated the rheological properties of high-performance FRC during the mixing process and studied the influence of steel fibers on the rheological properties and concluded that thixotropic behaviors increase with the addition of steel fibers [47]. The distribution and orientation of the steel fibers also have an impact on the rheological behavior [25,48-54].

However, it is found from the literature that the cohesion value is not yet related to the strength parameter and has not been determined using a vane shear apparatus. In this paper, fly ash and GGBS are replaced in cement paste and mortar in various combinations, and the corresponding flexural strength and splitting tensile strength are calculated. Using a reliable instrument, the vane shear apparatus, to conduct the rheology of the cement paste and mortar phase provides information about the rheology of concrete. The flow of the concrete is very dependent on the paste phase and mortar phase. Hence, equal importance is given to these phases in the study conducted on cement concrete. The cohesion of fresh cement and cement mortar (1:3 mixtures) was measured using a vane shear apparatus, which is currently used for laboratory testing of clay. The impact of the fly ash and GGBS on the shear strength characteristics of cement paste and mortar (1:3) for water/binder ratios $(\mathrm{w} / \mathrm{b})$ of 0.3 to 0.9 was studied. Mortar with and without mineral admixture was tested for flow table tests for the same $\mathrm{w} / \mathrm{b}$ ratios of 0.3 to 0.9 . The flexural strength and the splitting tensile strength of the above-mentioned mortar mixture were also investigated.

\section{Experimental Investigation}

This experimental study aimed to determine the rheological parameter and the cohesion of cement paste for a 1:3 mortar mix with varying $\mathrm{w} / \mathrm{b}$ ratios, from 0.3 to 0.9 , with the presence and absence of mineral admixtures of fly ash and GGBS. Further, the experiment also aimed to determine flexural strength and split tensile strength for various replacements of fly ash and GGBS and the combination of both. The material used for the preparation of mixtures is described in the following.

\subsection{Material Composition}

OPC (53 grade) was the main binder. The physical properties of the cement used are given in Table 1 and satisfy the requirements of Indian standards IS 12269-2015. In this study, good-quality river sand, free of silt and other impurities, was used. Table 2 lists the physical properties of fine aggregates evaluated by standard tests according to IS 383-2016. Fly ash was obtained from the Neyveli Thermal Power Station in Neville, India, 
and GGBFS was obtained from Andra Cement Co., Ltd., in Visakhapatnam, India. These were used to partially replace OPC. The physical and chemical properties of fly ash and GGBFS obtained through standard tests are listed in Table 3, and follow the standard code of IS 3812-2003 for fly ash and IS 16714:2018 for GGBS. Good-quality potable water was available during the experiments. All the material satisfies the standard requirement of the IS code.

Table 1. Properties of cement, fly ash, GGBS.

\begin{tabular}{ccccc}
\hline No. of Sample & Properties & Cement & Fly Ash & GGBS \\
\hline 1 & Specific gravity & 3.14 & 2.7 & 2.86 \\
2 & Standard consistency (\%) & 31 & 60 & 33 \\
& Setting_initial (min) & 55 & 30 & 120 \\
3 & Final (min) (Vicat needle) & 145 & 125 & 260 \\
& Compressive @ 3 days & 27.87 & 15.2 & - \\
4 & Strength @ 7 days & 38.85 & 16.3 & - \\
& N/mm ${ }^{2}$ @ 28 days & 55.86 & 23.1 & - \\
\hline
\end{tabular}

Table 2. Properties of fine aggregate.

\begin{tabular}{ccc}
\hline No. of Sample & Properties & Fine Aggregate \\
\hline 1 & Fineness modulus & 2.4 \\
2 & Density $\left(\mathrm{kg} / \mathrm{m}^{3}\right)$ & $1450-2082$ \\
3 & Specific gravity & 2.5 \\
4 & Water absorption & $2 \%$ \\
\hline
\end{tabular}

Table 3. Chemical characteristics of fly ash and GGBS (\%).

\begin{tabular}{cccc}
\hline No. of Sample & Chemical Composition & Fly Ash & GGBS \\
\hline 1 & Loss of ignition & 3.74 & 0.5 \\
2 & $\mathrm{SiO}_{2}$ & 35.87 & 29.47 \\
3 & $\mathrm{Fe}_{2} \mathrm{O}_{3}$ & 4 & 2.78 \\
4 & $\mathrm{Al}_{2} \mathrm{O}_{3}$ & 34.14 & 17.5 \\
5 & $\mathrm{CaO}$ & 14.25 & 33.43 \\
6 & $\mathrm{MgO}$ & 3.64 & 11.6 \\
7 & $\mathrm{SO}_{3}$ & 3.4 & 1 \\
8 & $\mathrm{Na}_{2} \mathrm{O}$ & 0.9 & 1.17 \\
9 & $\mathrm{~K}_{2} \mathrm{O}$ & 0.06 & 0.36 \\
10 & $\mathrm{Chloride}$ & - & 0.01 \\
\hline
\end{tabular}

\subsection{Preparation and Testing of Cement Paste and Cement Mortar}

In this study, we determined the cohesion of cement paste and mortar mixtures with varying $\mathrm{w} / \mathrm{b}$ ratios $(0.3,0.4,0.5,0.6,0.7,0.8$, and 0.9$)$. The mixture was prepared for the given $\mathrm{w} / \mathrm{b}$ ratio with and without fly ash and GGBS. In paste and mortar, fly ash replaced from $10 \%$ to $40 \%$, and GGBS replaced from $10 \%$ to $70 \%$. A flow table test was also performed on each mortar sample for all $\mathrm{w} / \mathrm{b}$ ratios. For each $\mathrm{w} / \mathrm{b}$ ratio, several mixtures were prepared for this study. Among all of these, one mixture was used as a reference mortar, and the remaining mixtures were composed of fly ash and GGBS. Flexural beams of size $40 \times 40 \times 160 \mathrm{~mm}$ were prepared for the 1:3 mortar mixes for $\mathrm{w} / \mathrm{b}$ ratios from 0.3 to 0.9 , cured in a curing tank, and tested for flexural strength at $7,14,28$, and 56 days. In addition, ASTM C348-21 [55] was used as a guide in determining the flexural strength test.

\section{Analyses and Discussions of the Results}

The paste and mortar mixtures without fly ash and GGBS were studied to determine their cohesion at various $\mathrm{w} / \mathrm{b}$ ratios. The flow table and strength characteristics of the mortar samples were also analyzed. 


\subsection{Rheological Behavior of Cement Paste and Mortar (with and without Mineral Admixture)}

It can be seen from the results that cohesion decreases with the increase of water content, since cement paste and cement mortar are improved by blending of mineral admixtures, fly ash, and GGBS. Therefore, even at a higher $\mathrm{w} / \mathrm{b}$ ratio, it is possible to produce a mixture with stability and fluidity in the presence of fly ash and GGBS without segregation. In the case of a GGBS mixture, the cohesion of the paste is increased to $100 \%$; in the case of a fly-ash-based mixture, to $30 \%$; and in the case of ternary blends, to less than $10 \%$ (i.e., using fly ash, GGBS, and OPC mixes) with respect to the reference paste mix (i.e., 100\% cement paste). Therefore, it is indicated that no matter what vibration force is involved, the ternary mixture can have better workability, since the ternary blend has less shear resistance to flow into the mold. For a binary mixture, that is, a mixture based on fly ash and GGBS, when a higher substitution amount is selected in the cement slurry, the shear resistance/cohesion of the mixture is higher, which may not give better results in terms of workability. However, it can provide good plastering and coating on surfaces, namely for masonry and construction applications.

\subsection{Cohesive Strength of Cement and Mortar}

The rheology of cement paste and mortar was studied by using vane shear equipment. The cohesion results of the paste and mortar are presented in Figure 1. For mortar mixtures, GGBS-based mortar mixtures exhibit higher cohesion, ranging from $140 \%$ to $240 \%$. In a fly-ash-based mixture, it is $20 \%$ to $130 \%$. Ternary blended mixes indicate improvement of cohesion, ranging from $10 \%$ to $130 \%$ with respect to the reference mortar. The zero value in Figure 1c-f reveal mixtures with segregation, that is, the shear stress or cohesion of these mixtures is negligible. Therefore, the mixture of ternary and fly ash is a flexible mixture, which can be compacted without vibration force (in concrete applications). In GGBS-based mixtures, cohesion is dominant, which can respond well to masonry applications. It is observed from the flow table test (Figure 1) that the flow values are higher for fly-ash- and ternary-based mixes as compared to the GGBS-based mixes. The maximum flow values are at $40 \%$ replacement of OPC with GGBS. The flow value is reduced at the higher and lower replacements of OPC with GGBS. In the case of fly ash mixes, the maximum flow values are at $20 \%$ replacement. At other replacements, the flow values are decreased. The above discussion shows that the maximum replacement levels for OPC are $40 \%$ for GGBS and $20 \%$ for fly ash, respectively.

As is clear from Figure 1, in all the cases the cohesion decreases with an increase in the $\mathrm{w} / \mathrm{b}$ ratio. It is observed from the graph that cohesion increases with an increase in the percentage of fly ash and GGBS content. Figure 1a shows that the cohesion is higher for the maximum replacement of fly ash. Figure $1 \mathrm{~b}$ demonstrates that cohesion is greater for the maximum replacement of GGBS. From Figure 1c, it is observed that the combination of the maximum replacement of GGBS and minimum replacement of fly ash exhibit higher cohesion. Compared to the paste phase, cohesion values are different in the case of mortar. Figure $1 \mathrm{f}$ shows that the cohesion value increases for the minimum replacement of fly ash, and in Figure 1g, the cohesion value increases for the minimum replacement of GGBS. Figure $1 \mathrm{f}$ indicates that $40 \%$ replacement of fly ash and $60 \%$ replacement GGBS exhibit maximum cohesion value.

\subsection{Workability of Mortar}

As regards the workability test, a flow table was conducted for mortar that consists of various $\mathrm{w} / \mathrm{b}$ ratios from 0.3 to 0.9 , for the various replacements of fly ash and GGBS, and the combination of both. In the case of ternary blends, the combination $20 \%$ OPC $+30 \%$ fly ash $+50 \%$ GGBS shows a higher flow value as compared with other ternary blended mixes. The $100 \%$ flow value shown in Figure 2a-c represents the flow spread of these mixes that takes place beyond the table. The increase in the flow value with respect to the $\mathrm{w} / \mathrm{b}$ ratios from 0.3 to 0.9 is $110 \%$ for the fly ash mixes, $119 \%$ for the GGBS mixes, and $102 \%$ for ternary blended mixes. At the normal consistency level of the mortar mixes where 
$\mathrm{w} / \mathrm{b}=0.4$, the maximum flow value is $61 \%$ for the ternary blended mix $(20 \%$ OPC $+30 \%$ fly ash $+50 \%$ GGBS), and the maximum cohesion is $78.2 \mathrm{~Pa}$ for the GGBS-based mix ( $30 \%$ OPC $+70 \%$ GGBS). Similarly, at the same $\mathrm{w} / \mathrm{b}=0.4$, the minimum flow value is $45.5 \%$ for $40 \%$ OPC $+60 \%$ GGBS, and the minimum cohesion is $33.5 \mathrm{~Pa}$ for $10 \%$ OPC $+40 \%$ fly ash $+50 \%$ GGBS.
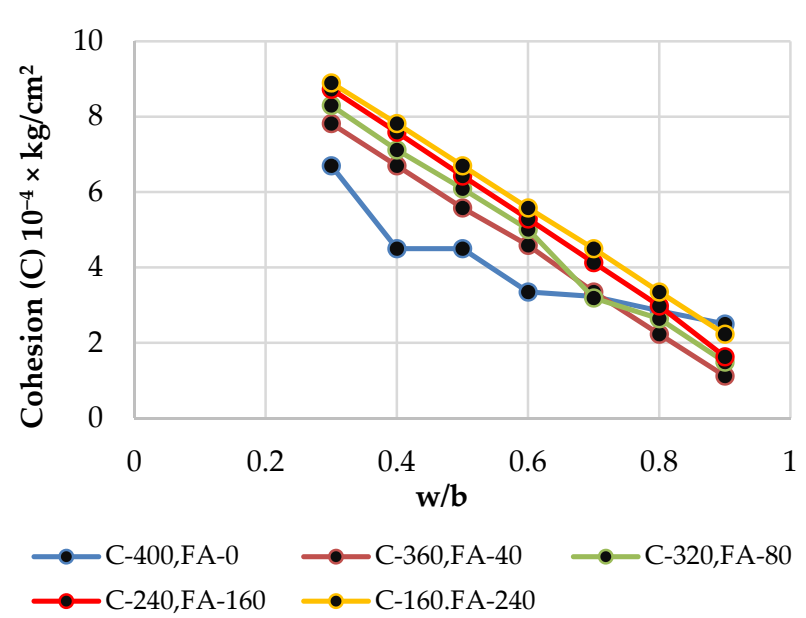

(a)

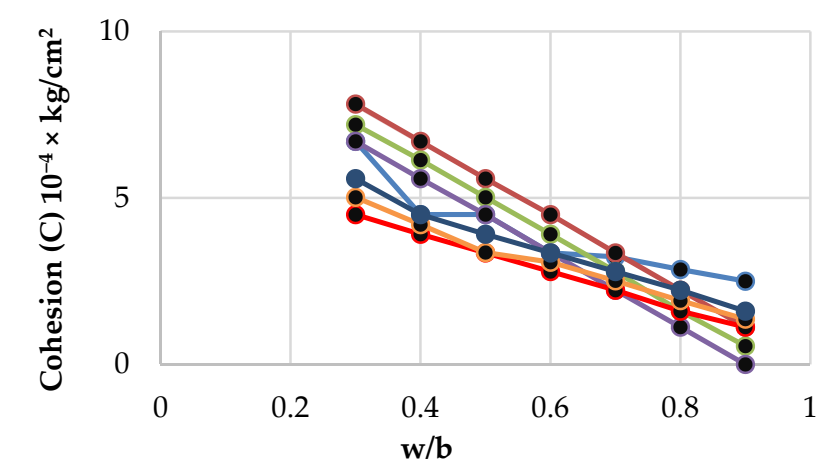

$\longrightarrow$ C-100,G-0,FA-0 $\longrightarrow$ C-10,G-70,FA-20 $\longrightarrow$ C-10,G-60,FA-30 $\longrightarrow$ C-20,G-40,FA-40 $\longrightarrow$ C-20,G-50,FA-30 $\longrightarrow$ C-20,G-50,FA-30

(c)

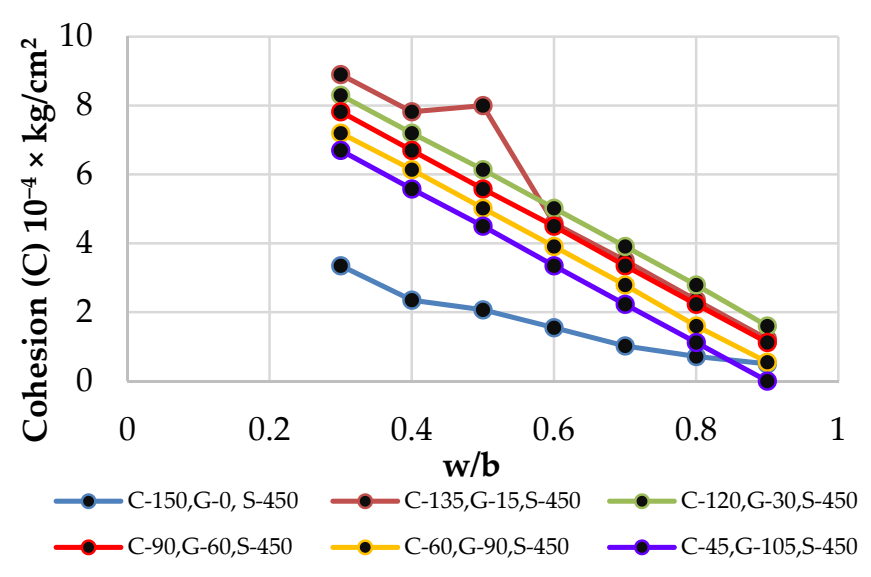

(e)

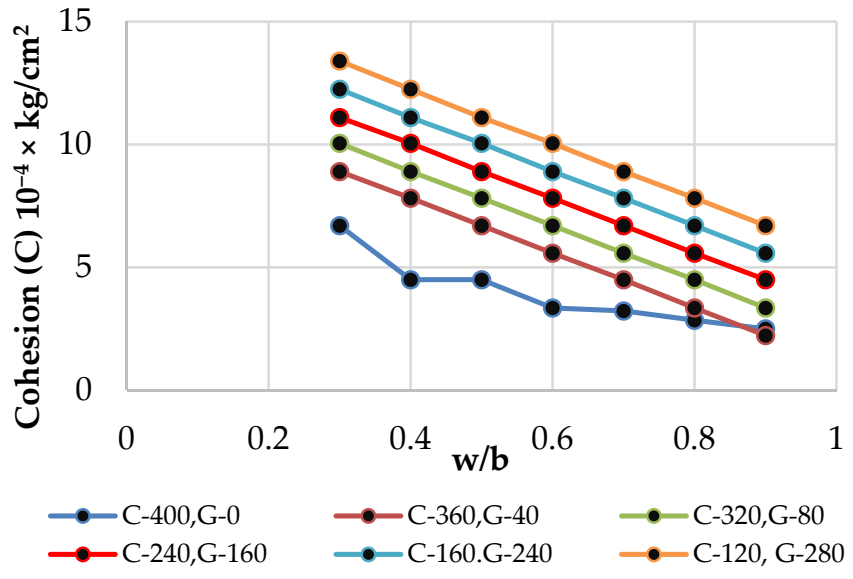

(b)

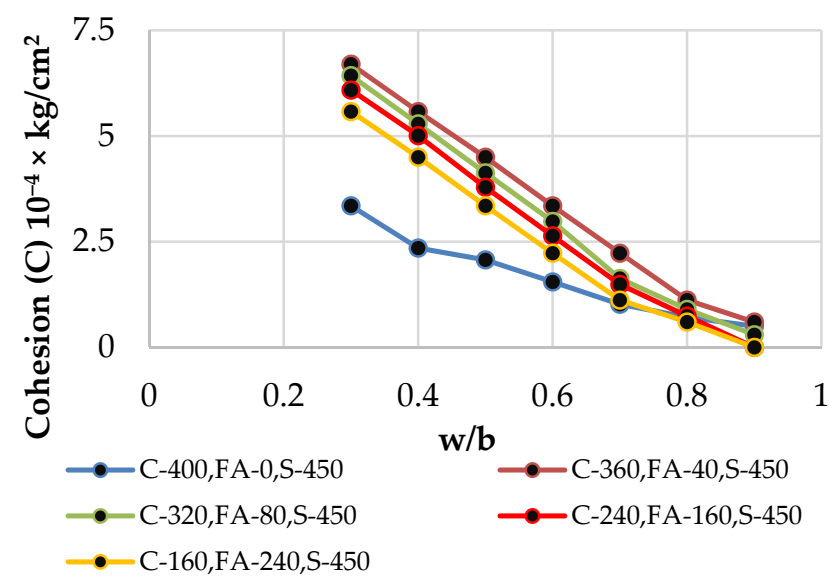

(d)

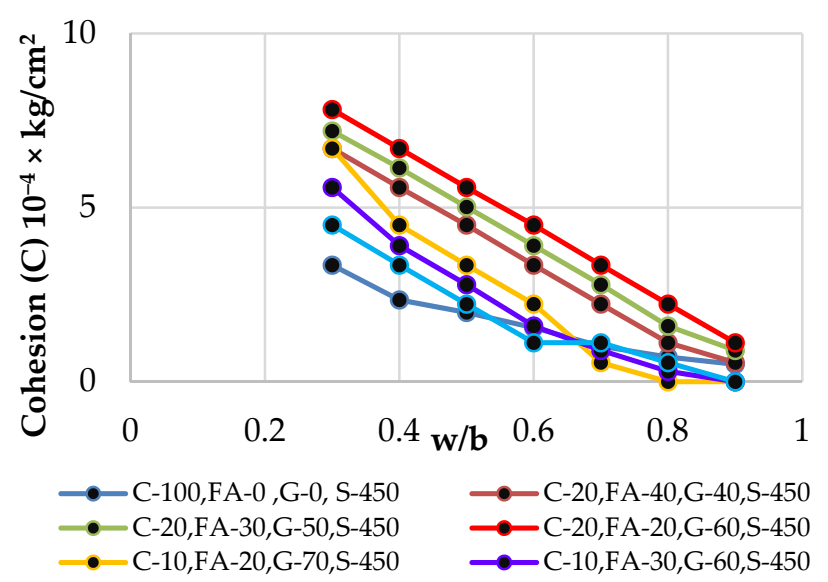

(f)

Figure 1. Cohesion for cement paste and cement mortar with composition of fly ash, GGBS, and ternary blend. C-cement, FA—fly ash, S-sand, G-GGBS; compositions are mentioned in gms for $(\mathbf{a}, \mathbf{b}, \mathbf{d}, \mathbf{e}), 10^{-4} \times \mathrm{kg} / \mathrm{cm}^{2},(\mathbf{c}, \mathbf{f})$ composition in $\%$. 


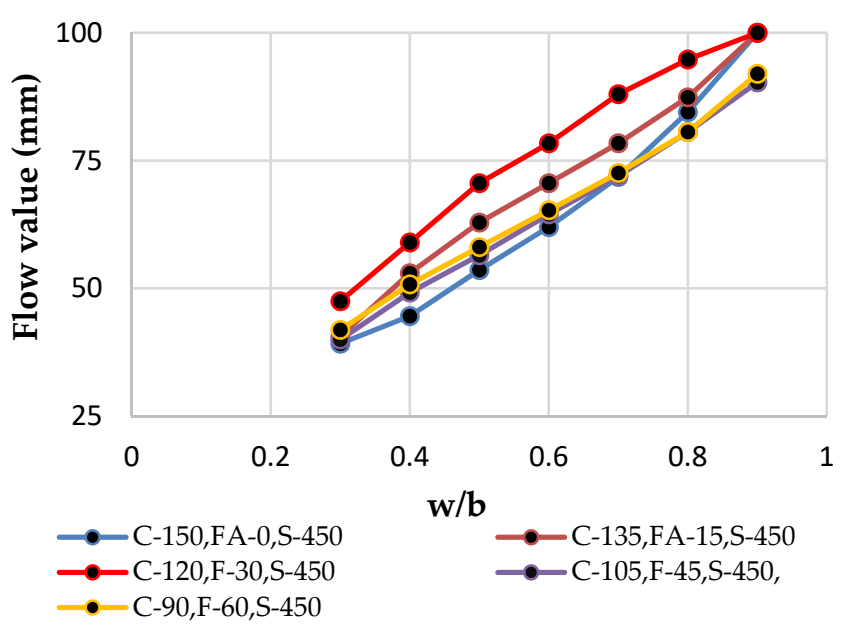

(a)

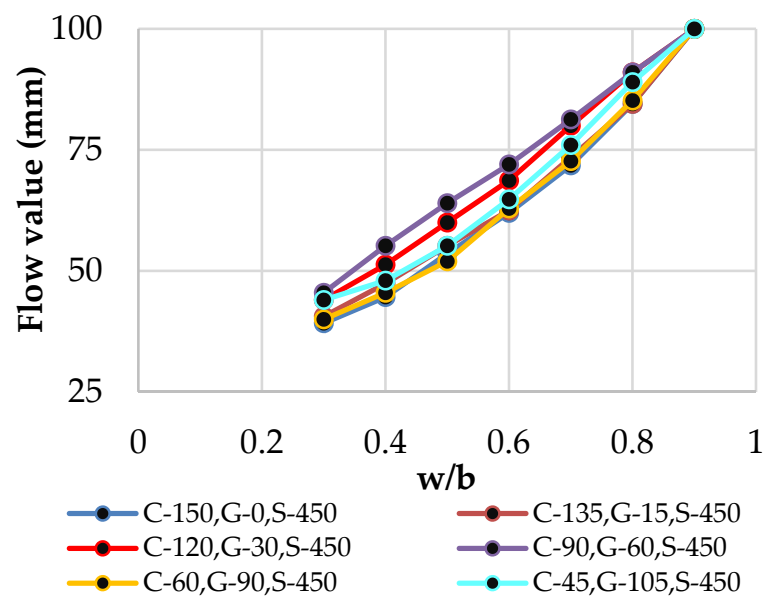

(b)

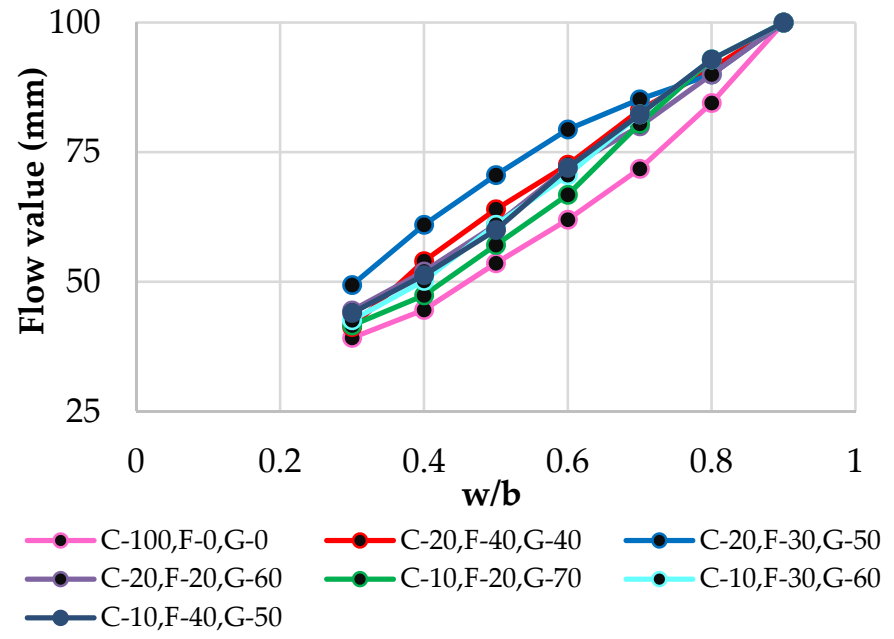

(c)

Figure 2. Flow value of 1:3 cement mortar with replacement of (a) fly ash, (b) GGBS, and (c) ternary blend. C—cement, S—sand, FA—fly ash, G-GGBS. Compositions are mentioned in $(\mathbf{a}, \mathbf{b})$ gms and (c) \%.

From Figure $2 \mathrm{a}$, it is obvious that $20 \%$ replacement of fly ash gives the maximum flow value. In Figure $2 b$, it is shown that $40 \%$ replacement with GGBS gives a higher flow value, and in the combination of fly ash and GGBS, from Figure 2c, 30\% fly ash and 50\% GGBS gives a higher flow value. The overall observation was that the minimum replacement of fly ash and 50\% replacement of GGBS give a higher flow value [56].

\subsection{Strength Characteristics of Cement Mortar}

The strength characteristics and flexural and splitting tensile strengths of cement mortar of 1:3 mixes with and without mineral admixtures (fly ash and GGBS) at $\mathrm{w} / \mathrm{b}$ ratios from 0.3 to 0.9 in all the mixes. From the results, the following observations are made. The flexural strength of cement mortar with various replacements of fly ash, GGBS, and ternary blend are shown in Figure 3. As fly ash increases from $10 \%$ to $40 \%$, the flexural strength decreases. The minimum decrease is $50 \%$ at $20 \%$ fly ash replacement with respect to the reference mortar strength, and the maximum decrease is $70 \%$ at $40 \%$ fly ash replacement with respect to the reference mortar strength. The flexural strength of fly ash-cement mortar increases for the $\mathrm{w} / \mathrm{b}$ ratios from 0.3 to 0.6 to that of the flexural strength at $\mathrm{w} / \mathrm{b}$ ratio 0.3 in 2 to 5 min time. 


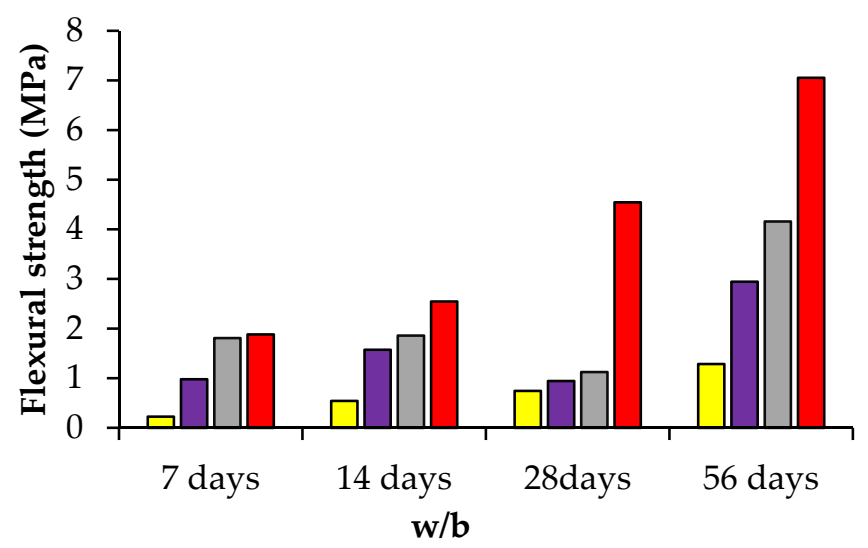

$\square 0.3 \mathrm{w} / \mathrm{b} \square 0.4 \mathrm{w} / \mathrm{b} \square 0.5 \mathrm{w} / \mathrm{b} \square 0.6 \mathrm{w} / \mathrm{b}$

(a)

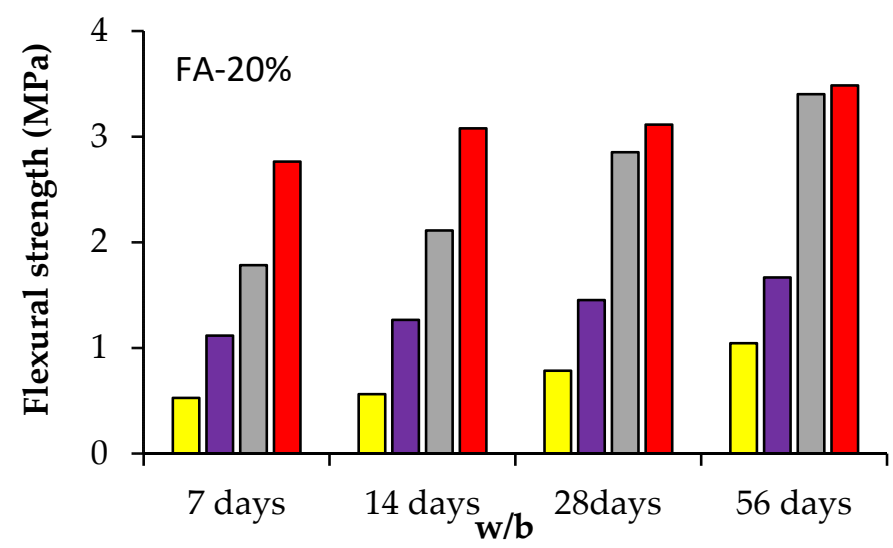

$\square 0.3 \mathrm{w} / \mathrm{b} \quad \square 0.4 \mathrm{w} / \mathrm{b} \quad \square 0.5 \mathrm{w} / \mathrm{b} \quad \square 0.6 \mathrm{w} / \mathrm{b}$

(c)

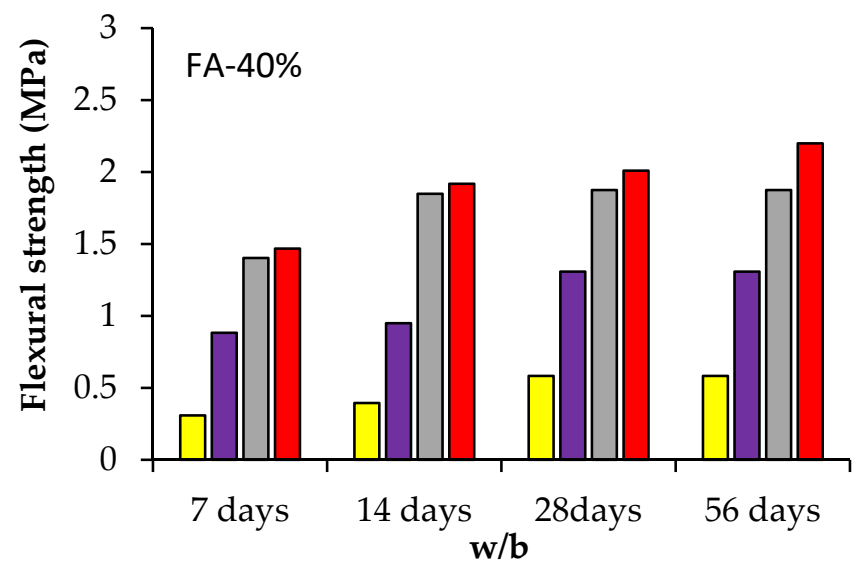

$\square 0.3 \mathrm{w} / \mathrm{b} \square 0.4 \mathrm{w} / \mathrm{b} \square 0.5 \mathrm{w} / \mathrm{b} \square 0.6 \mathrm{w} / \mathrm{b}$

(e)

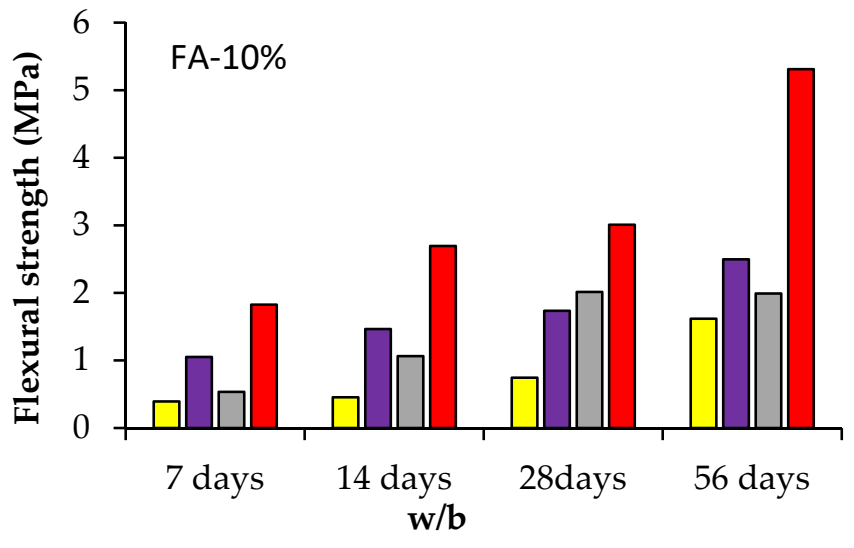

$\square 0.3 \mathrm{w} / \mathrm{b} \square 0.4 \mathrm{w} / \mathrm{b} \square 0.5 \mathrm{w} / \mathrm{b} \square 0.6 \mathrm{w} / \mathrm{b}$

(b)

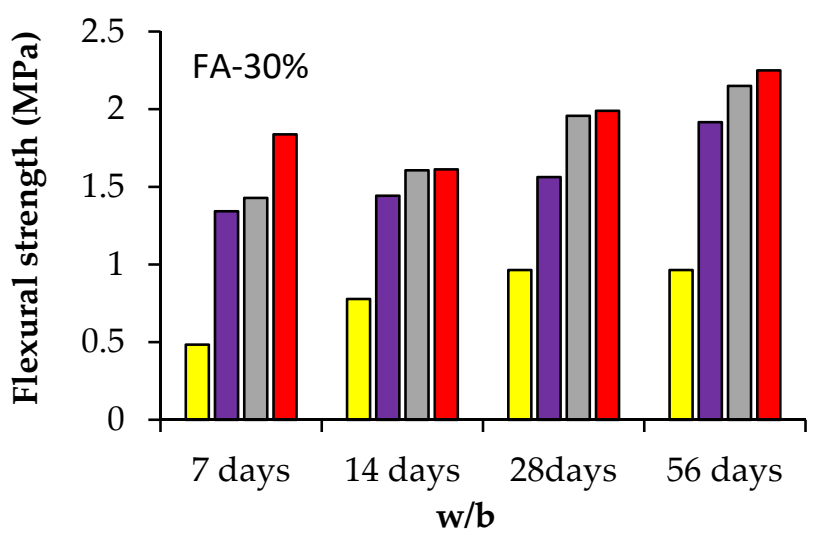

$\square 0.3 \mathrm{w} / \mathrm{b} \quad \square 0.4 \mathrm{w} / \mathrm{b} \quad \square 0.5 \mathrm{w} / \mathrm{b} \quad \square 0.6 \mathrm{w} / \mathrm{b}$

(d)

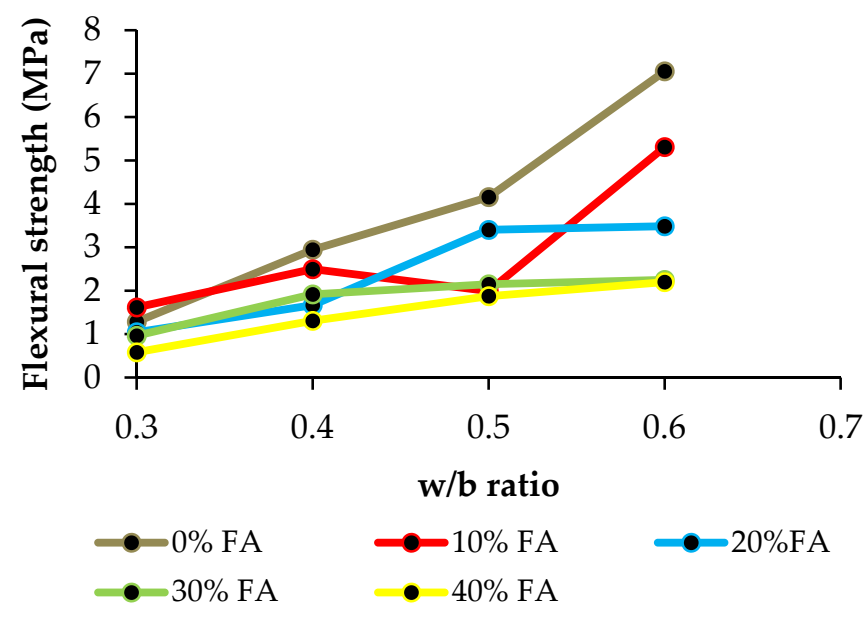

(f)

Figure 3. Flexural strength for cement mortar (1:3) with replacement of fly ash (FA): (a) 0\%, (b) 10\%, (c) 20\%, (d) $30 \%$, and (e) $40 \%$; (f) comparative chart for 56 days strength. 
From Figure 3a-e, it is observed that flexural strength is the largest value recorded at 56 days. From Figure $3 \mathrm{f}$, it is clear that $10 \%$ replacement of fly ash gives maximum flexural strength on 56 days. When compared to the reference mix, the strength is the lowest, but in the overall replacement of fly ash, $10 \%$ fly ash leads with good strength.

Figure 4 presents the various combinations of fly ash, GGBS, and cement for various $\mathrm{w} / \mathrm{b}$ ratios. In the reference and fly ash cement mortar, the flexural strength increases over the curing period. At 56 days of curing, the increase in flexural strength is in the range of 1.2 to 3.7 times that of the 7-days-cured strength. In the case of GGBS-cement mortar, the flexural strength increases with the length of curing from 7 days to 56 days for a $\mathrm{w} / \mathrm{b}$ ratio of 0.3 to 0.6 . At $20 \%$ GGBS, the percentage decrease in flexural strength is $26 \%$ compared to reference mortar for 56-days-cured specimens. The strength at $\mathrm{w} / \mathrm{b}$ ratio 0.6 is 2 to 4 times that of the strength at $\mathrm{w} / \mathrm{b}$ ratio 0.3 . The strength at 56 days curing is 1.5 to 2.5 times that of the strength at a w/b ratio of 0.3 . The strength at 56 days curing is 1.5 to 2.5 times that of the 7-days-cured specimens. Also, it is observed from Figure $4 \mathrm{a}-\mathrm{f}$ that the maximum flexural strength is obtained at 56 days. It is obvious from Figure $4 \mathrm{e}$ that $20 \%$ cement, $30 \%$ fly ash, and 60\% GGBS gives the maximum strength. An increase in the $\mathrm{w} / \mathrm{b}$ ratio increases the flexural strength.

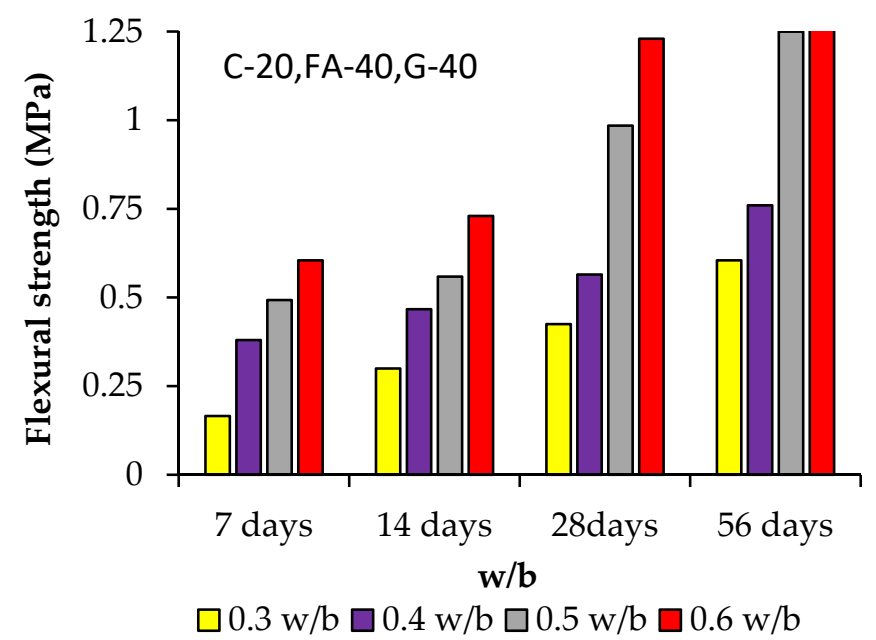

(a)

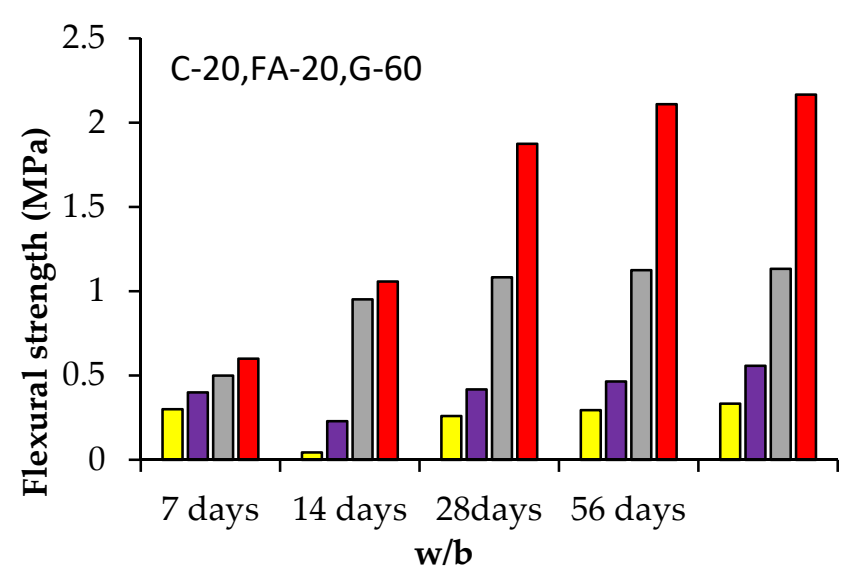

$\square 0.3 \mathrm{w} / \mathrm{b} \square 0.4 \mathrm{w} / \mathrm{b} \square 0.5 \mathrm{w} / \mathrm{b} \square 0.6 \mathrm{w} / \mathrm{b}$

(c)

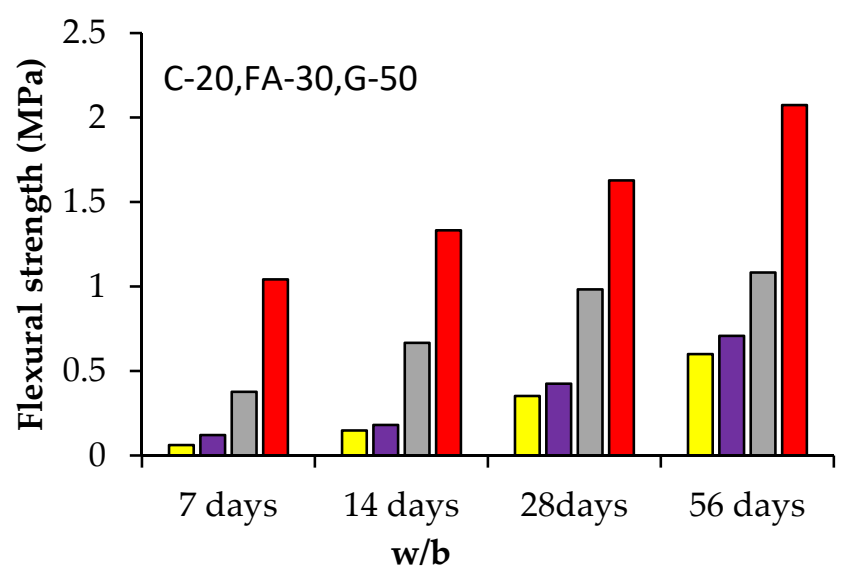

$\square 0.3 \mathrm{w} / \mathrm{b} \square 0.4 \mathrm{w} / \mathrm{b} \square 0.5 \mathrm{w} / \mathrm{b} \square 0.6 \mathrm{w} / \mathrm{b}$

(b)

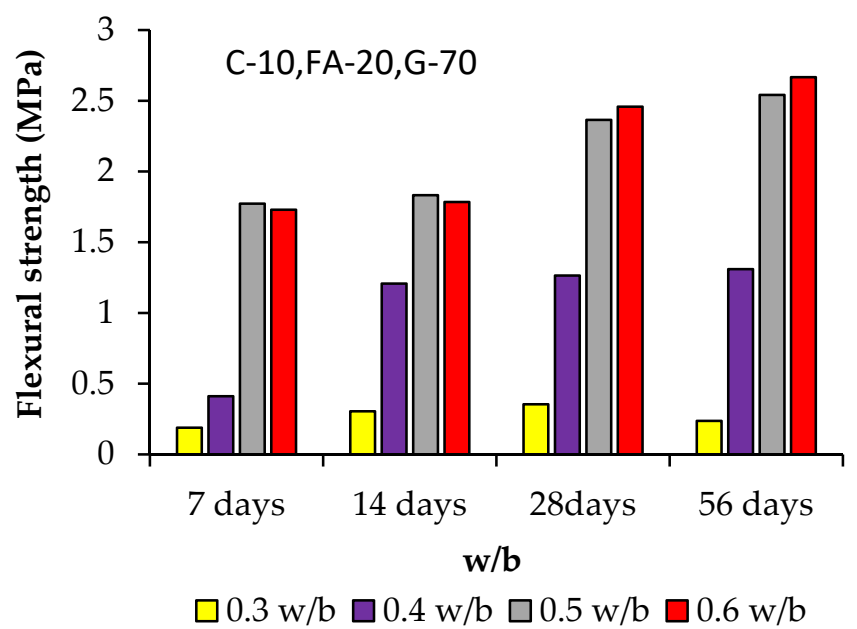

(d)

Figure 4. Cont. 

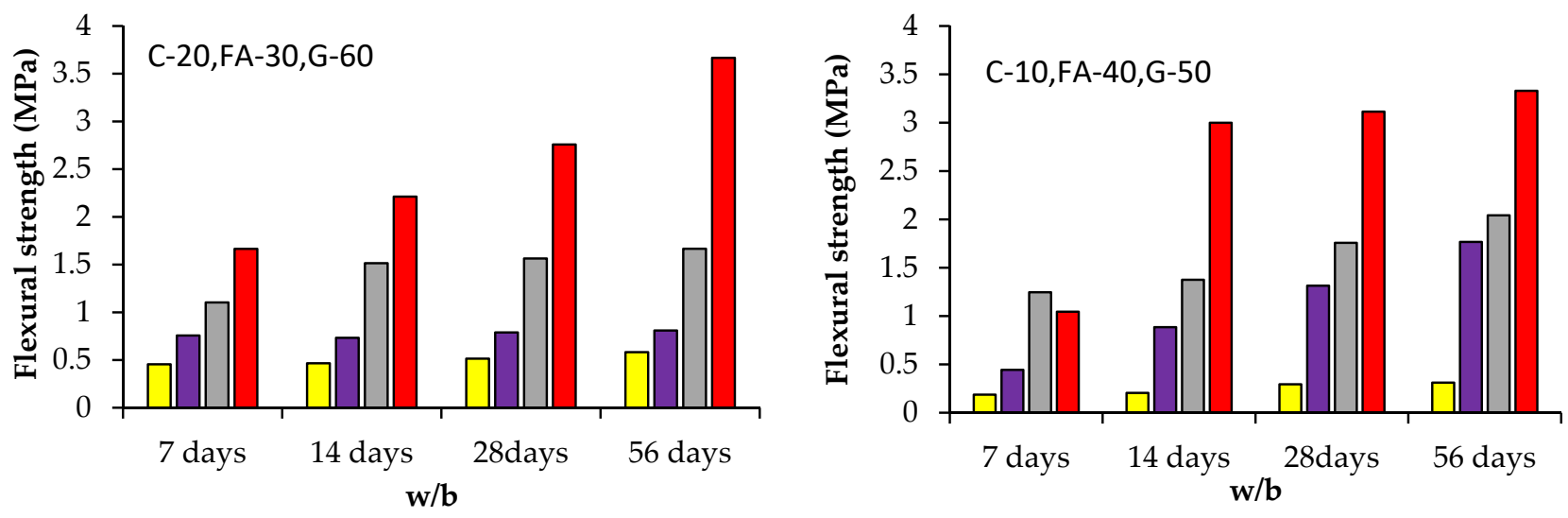

$\square 0.3 \mathrm{w} / \mathrm{b} \quad \square 0.4 \mathrm{w} / \mathrm{b} \quad \square 0.5 \mathrm{w} / \mathrm{b} \quad \square 0.6 \mathrm{w} / \mathrm{b}$

(e) $\square 0.3 \mathrm{w} / \mathrm{b}$

$\square 0.4 \mathrm{w} / \mathrm{b}$

(f)

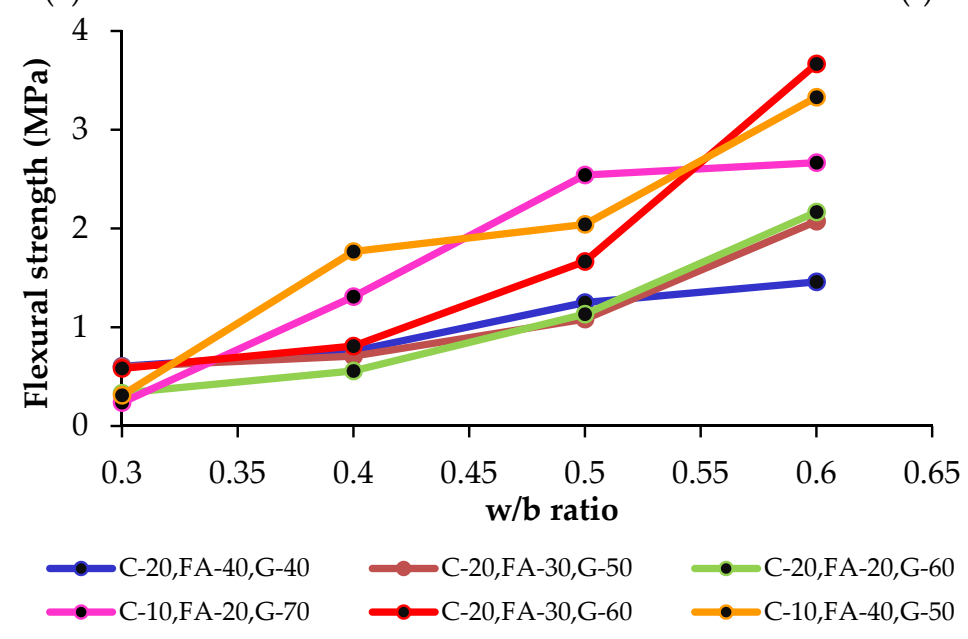

(g)

Figure 4. Flexural strength of cement mortar with replacement of fly ash and GGBS; C—cement, FA—fly ash, G-GGBS: (a) 0\%, (b) $10 \%$, (c) 20\%, (d) 30\%, (e) 40\%, (f) 50\%, and (g) comparative chart for 56 days strength, (compositions are given in \%).

Figure 5 shows flexural strength for the different replacements of GGBS for various $\mathrm{w} / \mathrm{b}$ ratios. In the case of cement-fly ash-GGBS mortar, the flexure strength is $48 \%$ less than the reference mortar strength. The strength at $\mathrm{w} / \mathrm{b}$ ratio 0.6 is 2.5 to 10.5 times that of the strength at $\mathrm{w} / \mathrm{b}$ ratio 0.3 . The flexural strength at 56 days curing is 1.5 to 3 times that of the 7-days-cured strength. It also shows that in all cases, 56 days shows higher strength. From Figure 5c, it is clear that 20\% replacement with GGBS exhibited the greatest flexural strength on 56-days. Meanwhile, it is found that at $10 \%$ replacement with GGBS (the minimum replacement rate) (Figure $5 b$ ) and at $60 \%$ replacement with GGBS (the maximum replacement rate) (Figure 5e), and even at $40 \%$ replacement with GGBS (Figure 5d), there is no significant improvement in flexural strength between the ages of 14 days and 28 days, and even at 56 days, meaning that the optimum replacement rate is at $20 \%$ replacement with GGBS, though other researchers have reported up to 35\% replacement of GGBS [3,42,57].

Figure 6 displays the different replacements of fly ash to determine the split tensile strength. The strength is determined for 7 days, 14 days, 28 days, and 56 days. The split tensile strength behavior is similar in trend to that of the flexural strength of the cement mortar with and without admixtures [58]. The decrease in split strength of fly ash-cement mortar (10\% fly ash) is $37 \%$ that of the reference mortar split tensile strength. The split tensile strength at a $\mathrm{w} / \mathrm{b}$ ratio of 0.6 is $8-48 \%$ higher than for the $0.3 \mathrm{w} / \mathrm{b}$ ratios. Split tensile strength at 56 days is $10-17 \%$ higher than the split tensile strength at 7 days. From Figure $6 \mathrm{~b}-\mathrm{e}$, it is clear that $20 \%$ replacement with GGBS had a slightly higher split tensile strength, without much difference at 14, 28, or 56 days, and was even similar to $10 \%$ 
replacement with GGBS. In the meantime, it is observed that at 30\% replacement with GGBS (with $0.3 \mathrm{w} / \mathrm{b}$ ) (Figure $5 \mathrm{~d}$ ) and at $40 \%$ replacement with GGBS (the maximum replacement rate, with $0.3 \mathrm{w} / \mathrm{b}$ ) (Figure $5 \mathrm{e}$ ), there was a slight reduction of split tensile strength, with similar trends for curing periods longer than 14 days. In addition, by examining Figure 6e, it can be concluded that at a $40 \%$ or higher replacement rate of GGBS, split tensile strength started significantly decreasing, regardless of the adopted $w / b$.

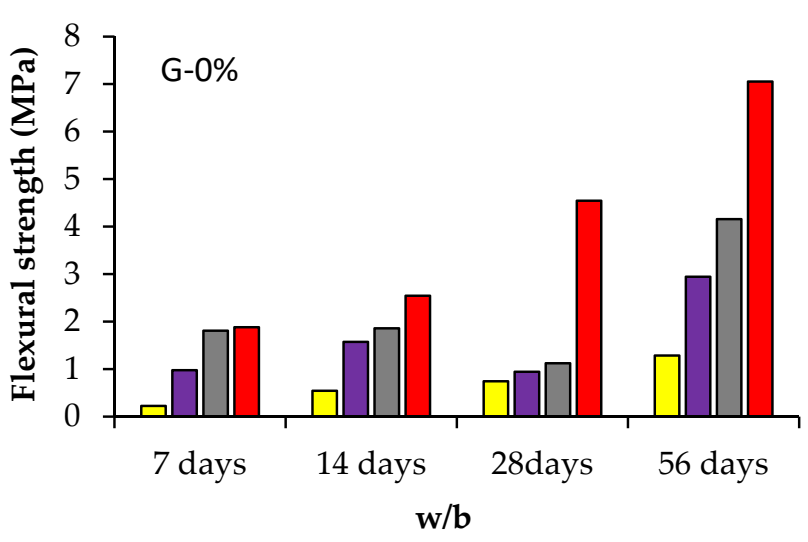

$\square 0.3 \mathrm{w} / \mathrm{b}$

$0.6 \mathrm{w} / \mathrm{b}$

(a)

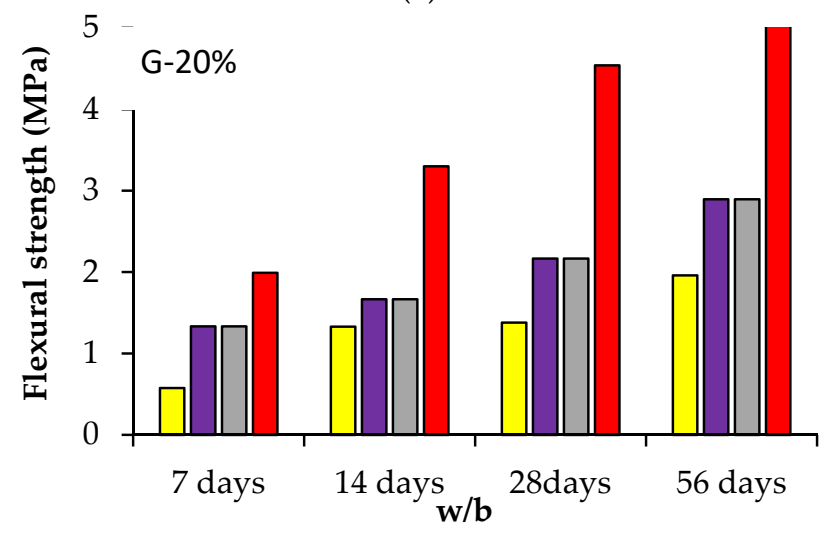

$\square 0.3 \mathrm{w} / \mathrm{b} \square 0.4 \mathrm{w} / \mathrm{b} \square 0.5 \mathrm{w} / \mathrm{b} \square 0.6 \mathrm{w} / \mathrm{b}$

(c)

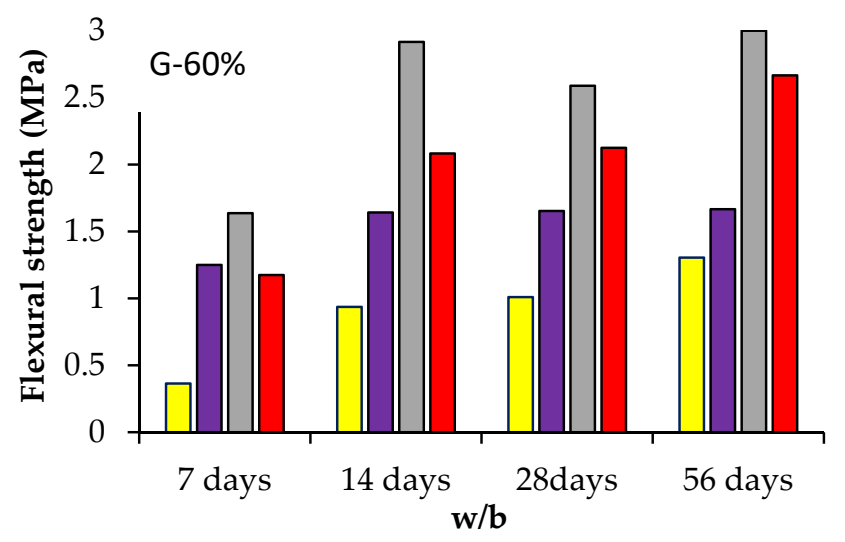

$\square 0.3 \mathrm{w} / \mathrm{b} \square 0.4 \mathrm{w} / \mathrm{b} \square 0.5 \mathrm{w} / \mathrm{b} \square 0.6 \mathrm{w} / \mathrm{b}$

(e)

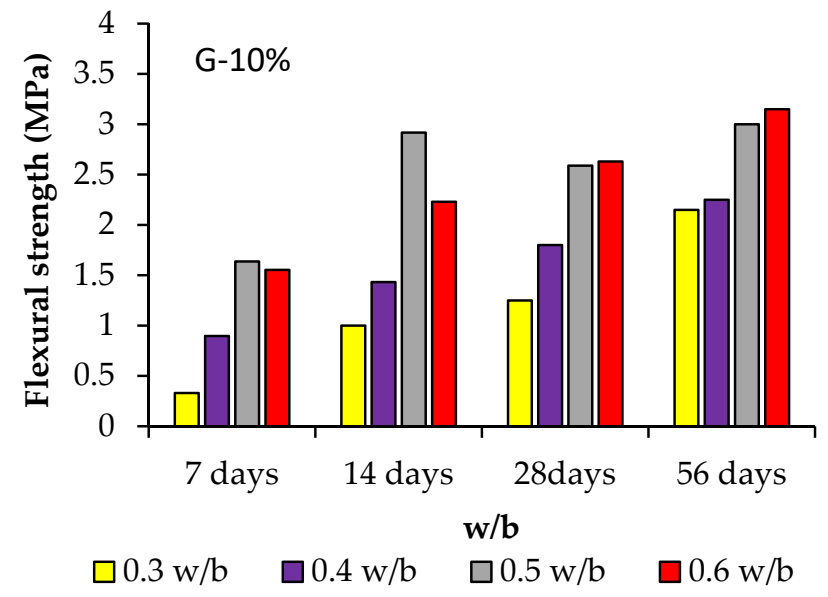

(b)

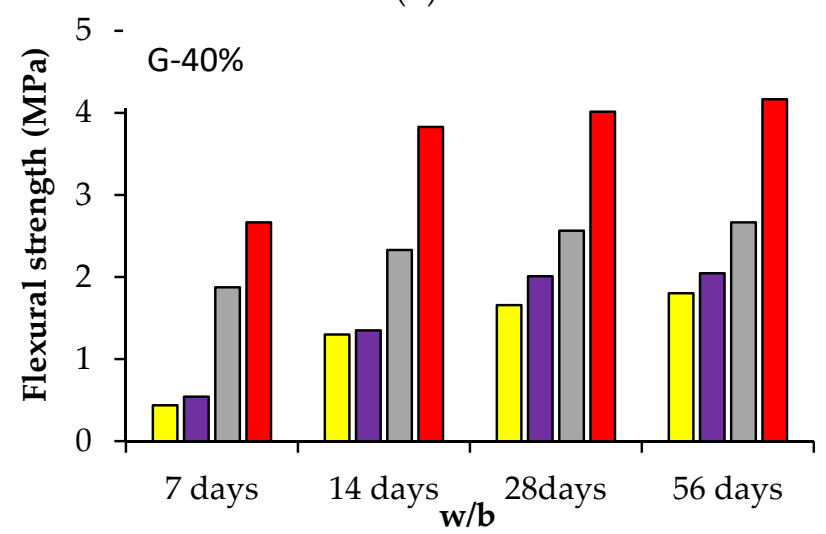

$\square 0.3 \mathrm{w} / \mathrm{b} \square 0.4 \mathrm{w} / \mathrm{b} \square 0.5 \mathrm{w} / \mathrm{b} \square 0.6 \mathrm{w} / \mathrm{b}$

(d)

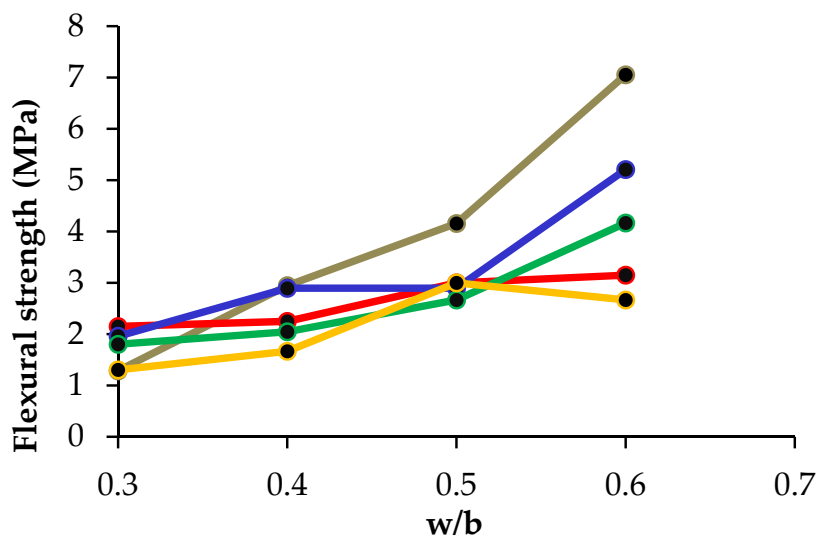

(f)

Figure 5. Flexural strength of cement mortar (1:3) with replacement of GGBSG-GGBS: (a) 0\%, (b) 10\%, (c) 20\%, (d) 30\%, and (e) $40 \%$; (f) comparative chart for 56 days strength, (compositions are given in \%). 


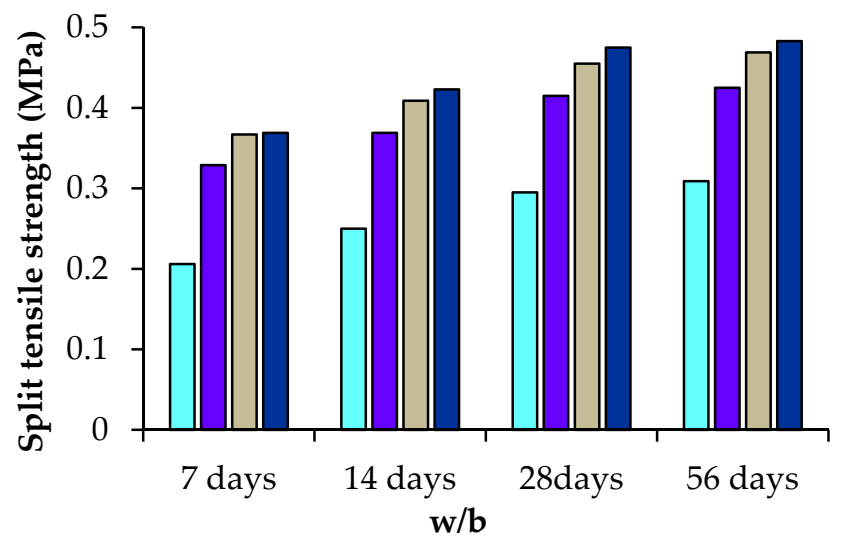

$\square 0.3 \mathrm{w} / \mathrm{b} \quad \square 0.4 \mathrm{w} / \mathrm{b} \quad \square 0.5 \mathrm{w} / \mathrm{b} \quad \square 0.6 \mathrm{w} / \mathrm{b}$

(a)

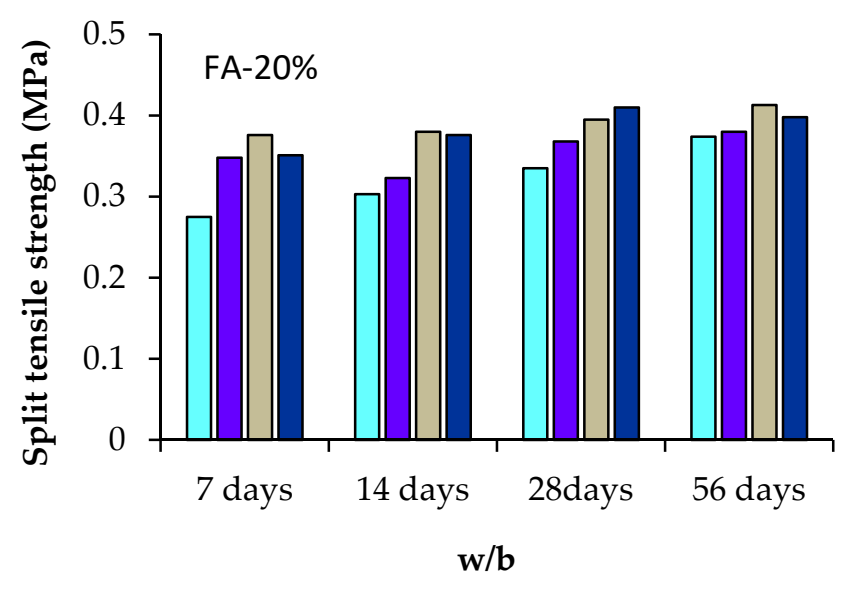

$\square 0.3 \mathrm{w} / \mathrm{b} \square 0.4 \mathrm{w} / \mathrm{b} \square 0.5 \mathrm{w} / \mathrm{b} \square 0.6 \mathrm{w} / \mathrm{b}$

(c)

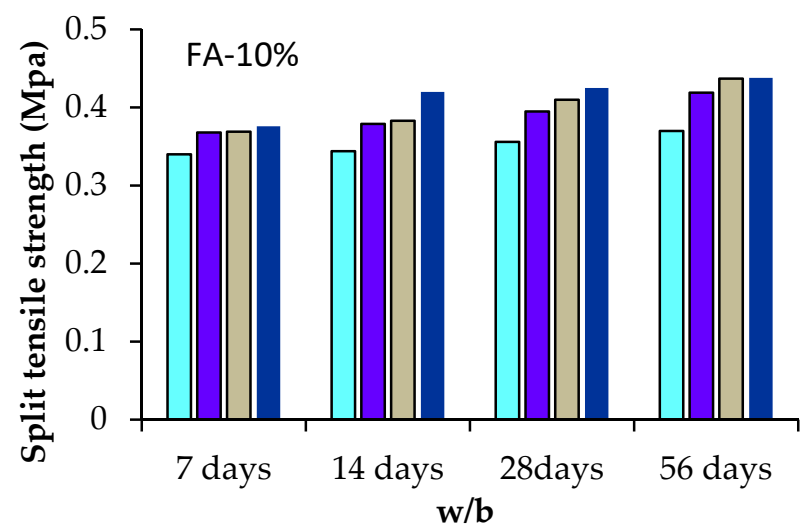

$\square 0.3 \mathrm{w} / \mathrm{b} \quad \square 0.4 \mathrm{w} / \mathrm{b} \quad \square 0.5 \mathrm{w} / \mathrm{b} \quad \square 0.6 \mathrm{w} / \mathrm{b}$

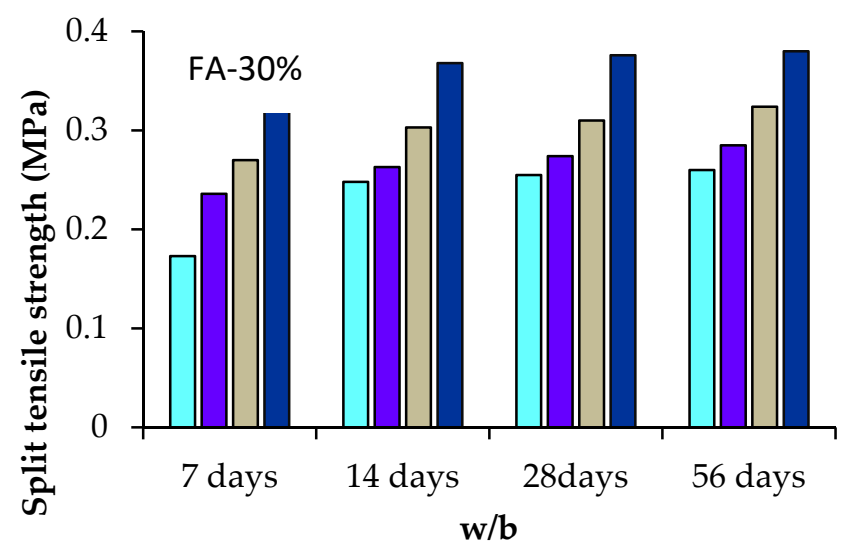

$\square 0.3 \mathrm{w} / \mathrm{b} \square 0.4 \mathrm{w} / \mathrm{b} \square 0.5 \mathrm{w} / \mathrm{b} \square 0.6 \mathrm{w} / \mathrm{b}$

(d)

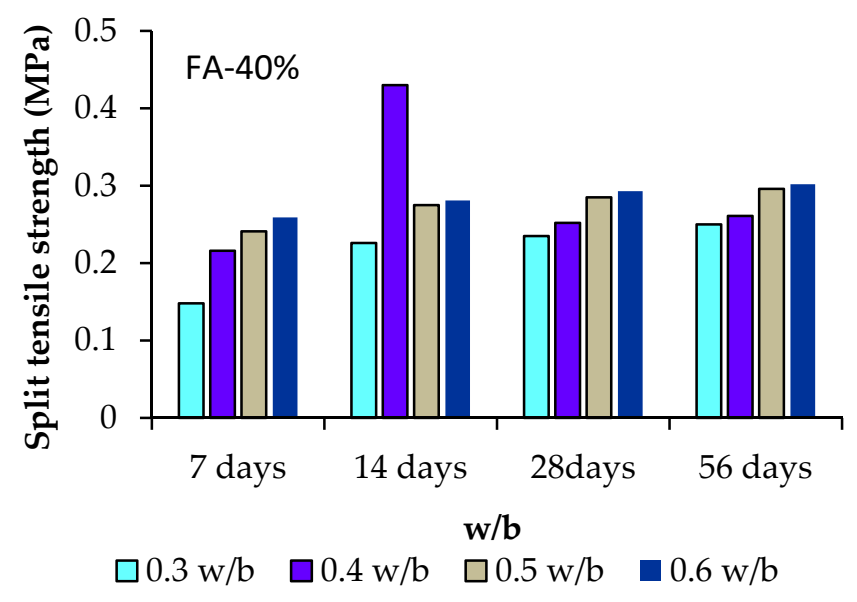

(e)

Figure 6. Split tensile strength of fly ash cement mortar (1:3). FA—fly ash: (a) $0 \%$, (b) 10\%, (c) 20\%, (d) 30\%, and (e) $40 \%$, (compositions are given in \%).

Figure 7 illustrates the different combinations of cement, fly ash, and GGBS and their split tensile strengths. The split tensile strength of the GGBS cement mortar with $20 \%$ replacement with GGBS is almost equal to the split tensile strength of the reference mortar. There is an improvement of $78 \%$ to $110 \%$ at a w/b ratio of 0.6 as compared to the 7 days split tensile strength. 


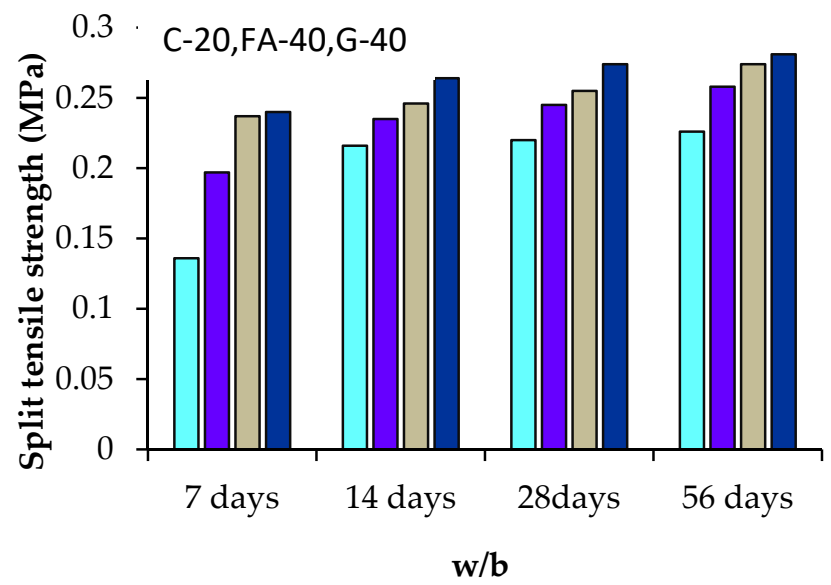

$\square 0.3 \mathrm{w} / \mathrm{b} \quad \square 0.4 \mathrm{w} / \mathrm{b} \quad \square 0.5 \mathrm{w} / \mathrm{b} \quad \square 0.6 \mathrm{w} / \mathrm{b}$

(a)

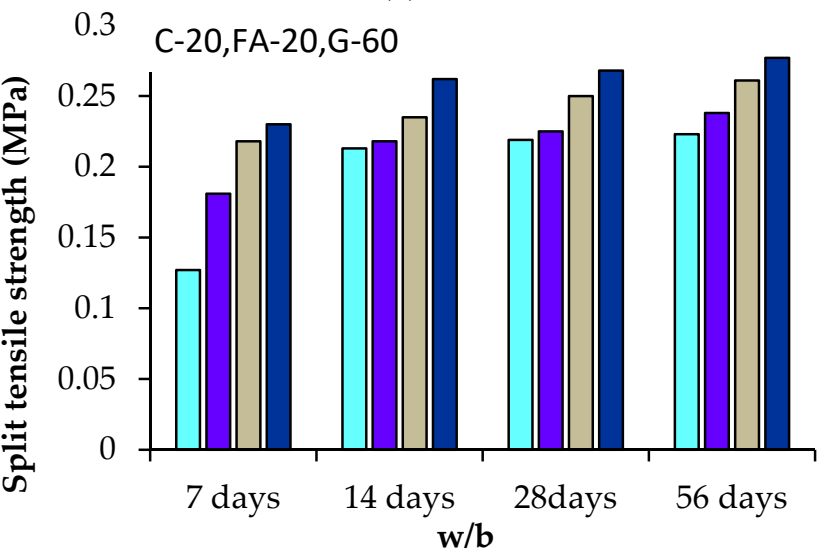

$\square 0.3 \mathrm{w} / \mathrm{b} \square 0.4 \mathrm{w} / \mathrm{b} \square 0.5 \mathrm{w} / \mathrm{b} \square 0.6 \mathrm{w} / \mathrm{b}$

(c)

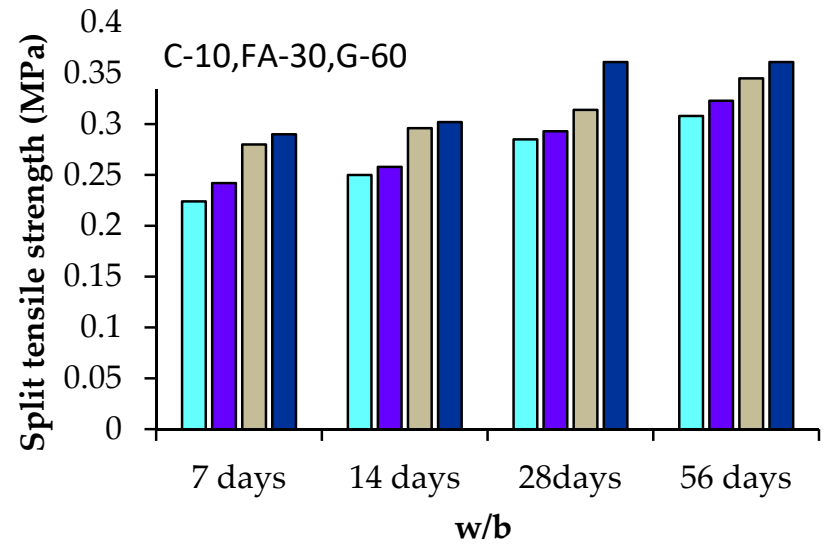

$\square 0.3 \mathrm{w} / \mathrm{b} \square 0.4 \mathrm{w} / \mathrm{b} \square 0.5 \mathrm{w} / \mathrm{b} \square 0.6 \mathrm{w} / \mathrm{b}$

(e)

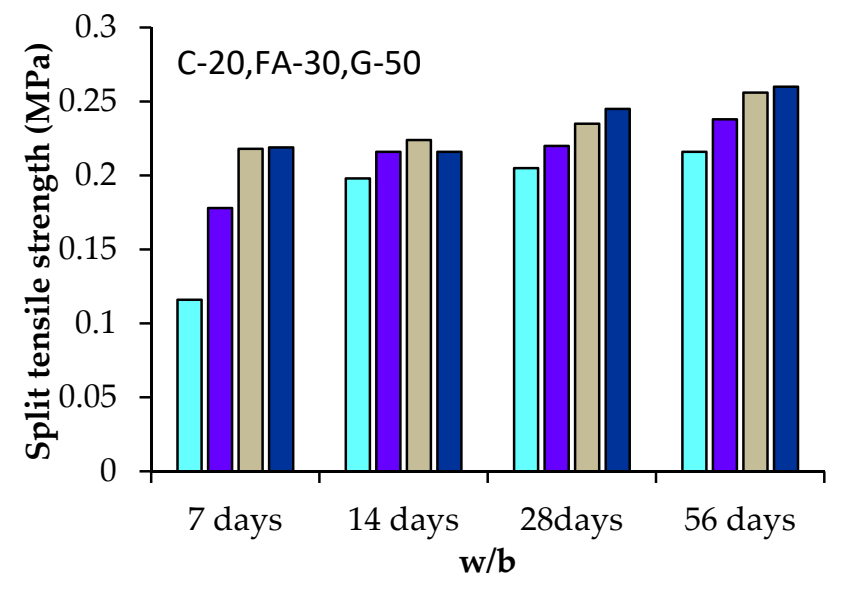

$\square 0.3 \mathrm{w} / \mathrm{b} \quad 0.4 \mathrm{w} / \mathrm{b} \quad \square 0.5 \mathrm{w} / \mathrm{b} \quad \square 0.6 \mathrm{w} / \mathrm{b}$

(b)

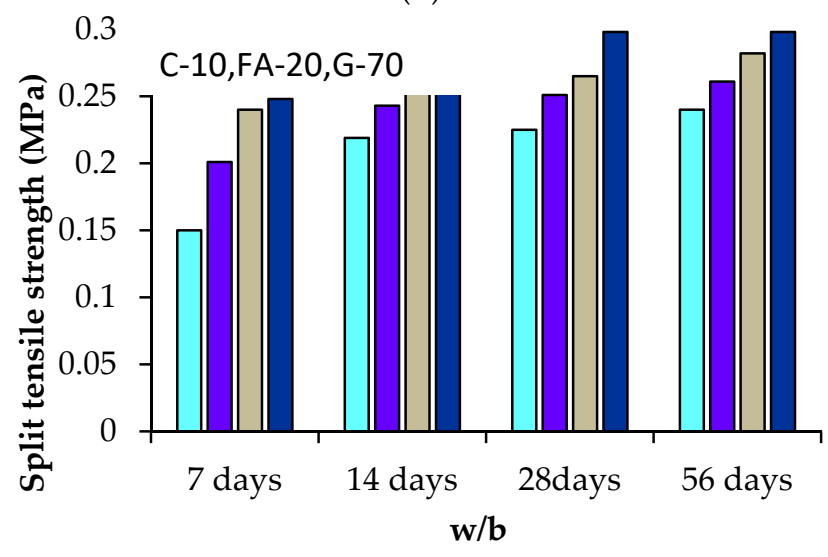

$\square 0.3 \mathrm{w} / \mathrm{b} \square 0.4 \mathrm{w} / \mathrm{b} \square 0.5 \mathrm{w} / \mathrm{b} \square 0.6 \mathrm{w} / \mathrm{b}$

(d)

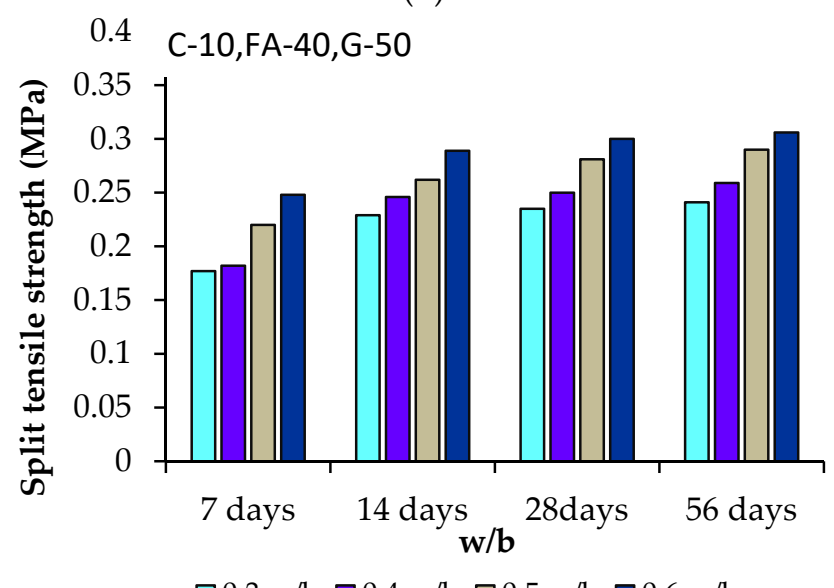

$\square 0.3 \mathrm{w} / \mathrm{b} \square 0.4 \mathrm{w} / \mathrm{b} \square 0.5 \mathrm{w} / \mathrm{b} \square 0.6 \mathrm{w} / \mathrm{b}$

(f)

Figure 7. Split tensile strength of fly ash + GGBS cement mortar (1:3). C—cement, FA—fly ash, G—GGBS: (a) 0\%, (b) 10\%, (c) $20 \%$, (d) $30 \%$, (e) $40 \%$, and (f) $50 \%$, (composition given in $\%$ ).

Figure 8 demonstrates the different replacements of GGBS and their split tensile strengths. The split tensile strength of the fly ash-GGBS cement mortar is $25 \%$ less than the reference mortar strength. At a w/b ratio of 0.6 , the split tensile strength is $17 \%$ to $27 \%$ higher than at a $\mathrm{w} / \mathrm{b}$ ratio of 0.3 . The tensile strength is $20 \%$ higher than the reference specimen, at the ages of both 7 and 28 days. 


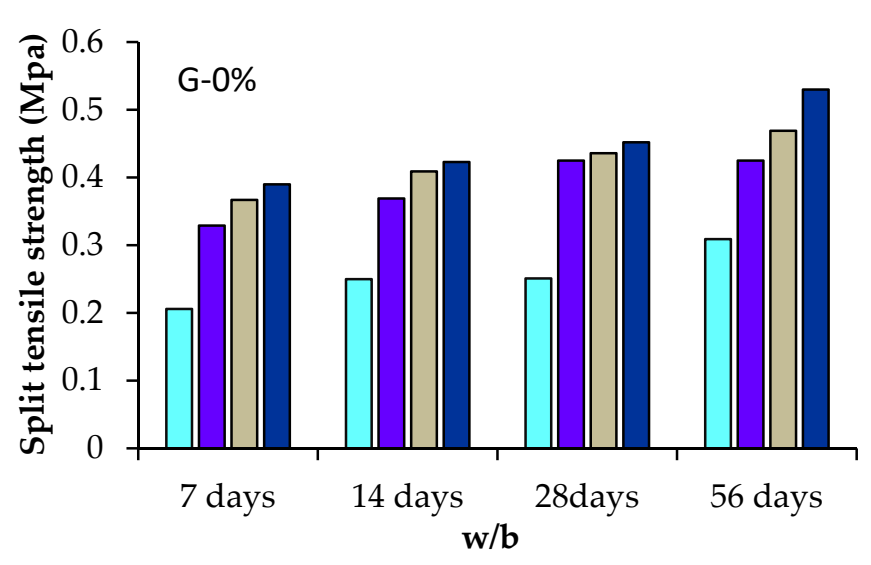

$\square 0.3 \mathrm{w} / \mathrm{b} \square 0.4 \mathrm{w} / \mathrm{b} \square 0.5 \mathrm{w} / \mathrm{b} \square 0.6 \mathrm{w} / \mathrm{b}$

(a)

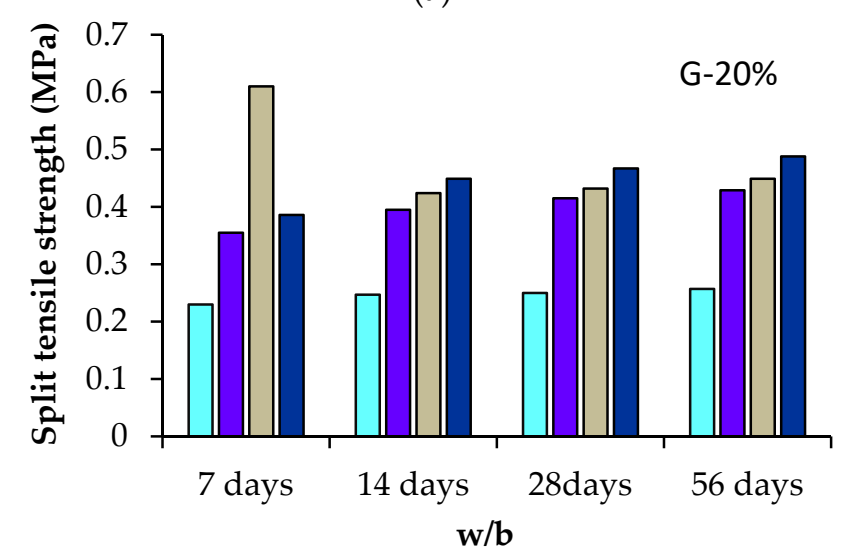

$\square 0.3 \mathrm{w} / \mathrm{b} \quad \square 0.4 \mathrm{w} / \mathrm{b}$

(c)

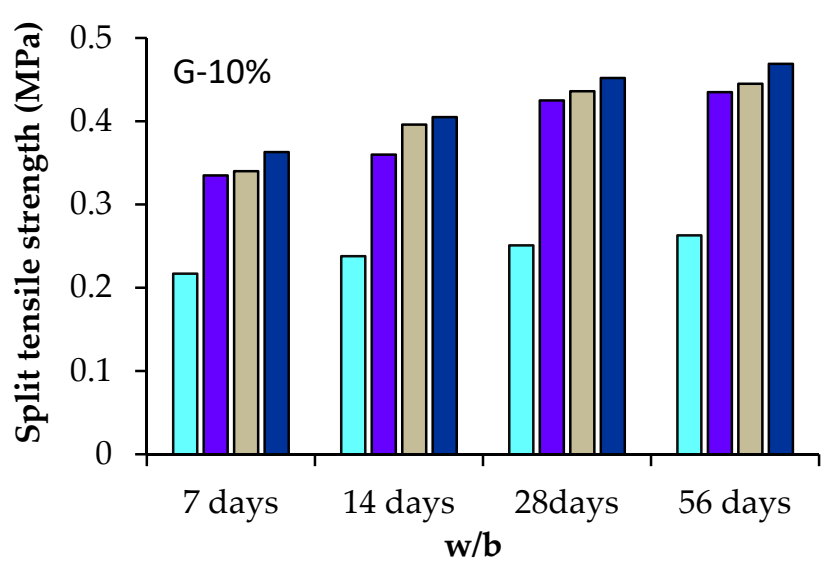

$\square 0.3 \mathrm{w} / \mathrm{b} \square 0.4 \mathrm{w} / \mathrm{b} \square 0.5 \mathrm{w} / \mathrm{b} \square 0.6 \mathrm{w} / \mathrm{b}$

(b)

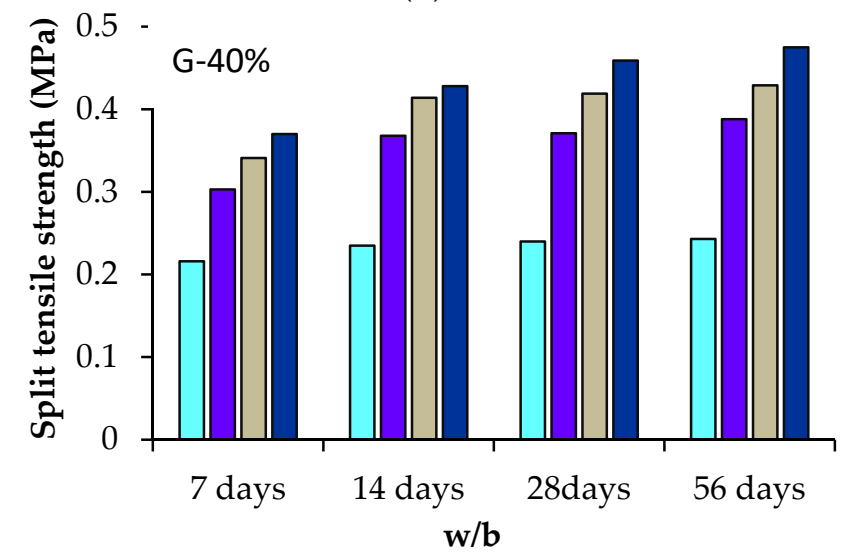

$\square 0.3 \mathrm{w} / \mathrm{b} \square 0.4 \mathrm{w} / \mathrm{b} \square 0.5 \mathrm{w} / \mathrm{b} \square 0.6 \mathrm{w} / \mathrm{b}$

(d)

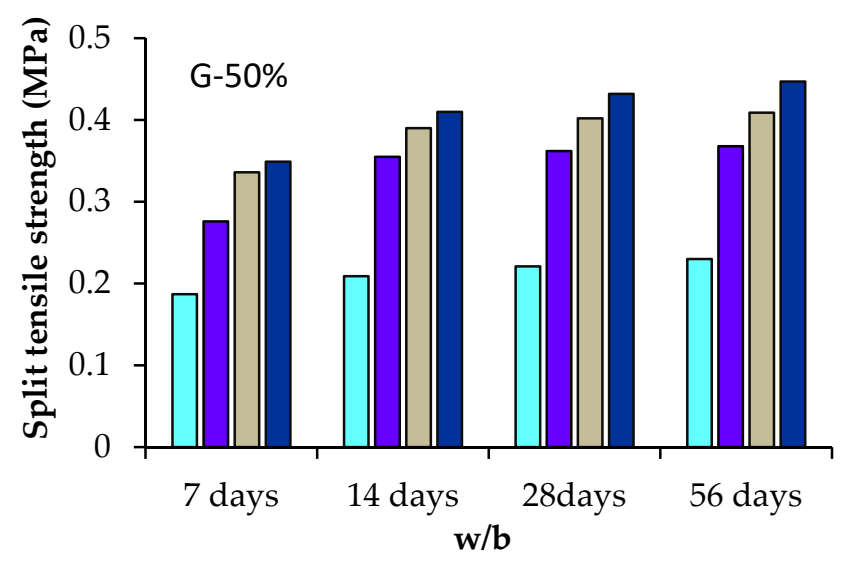

$\square 0.3 \mathrm{w} / \mathrm{b} \square 0.4 \mathrm{w} / \mathrm{b} \square 0.5 \mathrm{w} / \mathrm{b} \square 0.6 \mathrm{w} / \mathrm{b}$

(e)

Figure 8. Split tensile strength of GGBS cement mortar (1:3). G-GGBS: (a) 0\%, (b) 10\%, (c) 20\%, (d) 30\%, and (e) 40\%, (composition mentioned in \%).

\section{Conclusions}

Based on the presented experimental investigations on the rheological behavior of cement paste and cement mortar, with and without fly ash and GGBS, the following conclusions can be drawn: 
- $\quad$ The cohesion of the binary blended (fly ash + OPC; GGBS + OPC) paste mixes increases with an increase in the content of both mineral admixtures at a particular $\mathrm{w} / \mathrm{b}$ ratio.

- In the case of ternary blended paste mixes (OPC + fly ash + GGBS), the cohesion improves with increases in the GGBS content and cohesion decreases with an increase in the fly ash content.

- GGBS-based paste mixes can be suggested for ornamental and masonry applications, as the cohesion of these mixes is higher than the fly ash mixes and the ternary blend mixes.

- $\quad$ At the $\mathrm{w} / \mathrm{b}$ ratio of 0.4 , the maximum cohesion reported is $111 \mathrm{~Pa}$ for GGBS, 78.12 Pa for fly ash, and $67 \mathrm{~Pa}$ for ternary blended cement pastes, respectively.

- As in the pastes, a similar behavior is observed for various mortars mixes (1:3). GGBS-cement mortar mixes show slightly higher cohesion than the fly ash-cement and ternary blended mortars.

- The cohesion of the paste mixes is higher than that of the corresponding mortar mixes. This is due to the thickening of the water films surrounding the sand grains of the mortar mixes, resulting in increased inter-particle distance and decreased flocculation forces.

- The maximum cohesion observed in the experimental investigation for the mortar mixes at $\mathrm{w} / \mathrm{b}$ ratio 0.4 is 78.2 Pa for GGBS-cement mortar, 55.8 Pa for fly ash-cement mortar, and $67 \mathrm{~Pa}$ for GGBFS-fly ash-cement mortar, respectively.

- The flow behavior of the mortar mixes is inversely proportional to the cohesion of similar mortar mixes.

- $\quad$ Irrespective of the type of mortar mix at a $\mathrm{w} / \mathrm{b}$ ratio of 0.6 , the maximum flexural and split tensile strengths are reached.

- $\quad$ Both the flexural and split tensile strength of the mortar mixes increases with an increase in the age of curing.

- At $20 \%$ fly ash and at the age of 56 days, the maximum flexural and split tensile strengths are $3.486 \mathrm{MPa}$ and $0.413 \mathrm{MPa}$, respectively.

- $\quad$ At $20 \%$ GGBS and at the age of 56 days, the maximum flexural and split tensile strengths are $5.208 \mathrm{MPa}$ and $0.488 \mathrm{MPa}$, respectively.

- $\quad$ For the blended (10\% OPC + 30\% fly ash + 60\% GGBS) mortar mix and at the age of 56 days, the maximum flexural strength was $3.667 \mathrm{MPa}$ and the maximum split tensile strength was $0.361 \mathrm{MPa}$.

The results indicate that in the presence of a mineral mixture of fly ash and GGBS, the rheological behavior of paste and mortar is similar. Compared with OPC-GGBS-based mixtures, both cement-fly ash and ternary mixtures show less shear resistance or impact resistance. The rheological behavior of the mortar also matches the rheological behavior in the flow table test. Therefore, it is easy to use the vane shear test equipment to conduct cohesion studies to understand the properties of cement paste and mortar using mineral admixtures. The strength results show that the long-term strength of GGBS-based mixtures and ternary mixed mixtures is better than that of fly-ash-based mixtures. For all mixtures, the strength characteristics are greatest at a $\mathrm{w} / \mathrm{b}$ ratio of 0.6 .

Author Contributions: Conceptualization, V.A., P.T. and E.I.S.F.; data curation, M.A., R.F., N.V. and M.K.; formal analysis, V.A., P.T., S.A. and M.A.; funding acquisition, M.A., R.F., N.V. and M.K.; investigation, V.A. and P.T.; methodology, V.A., P.T. and S.A.; project administration, M.A.; resources, S.A., E.I.S.F., M.A. and N.V.; supervision, E.I.S.F.; validation, E.I.S.F., M.A., R.F. and M.K.; visualization, N.V.; writing-original draft, V.A., P.T. and S.A.; writing-review and editing, E.I.S.F., M.A., R.F., N.V. and M.K. All authors have read and agreed to the published version of the manuscript.

Funding: The research was funded by the Ministry of Science and Higher Education of the Russian Federation as the grant Self-Healing Construction Materials (contract No. 075-15-2021-590 dated 4 June 2021).

Institutional Review Board Statement: Not applicable. 
Informed Consent Statement: Not applicable.

Data Availability Statement: Not applicable.

Acknowledgments: S. Avudaiappan and E.I. Saavedra Flores acknowledge funding from Universidad de Santiago de Chile, Usach, Project AP_539SF, DICYT, University of Santiago de Chile, Vicerrectoría de Investigación, Desarrollo e Innovación.

Conflicts of Interest: The authors declare no conflict of interest.

\section{References}

1. Makul, N.; Fediuk, R.; Amran, M.; Zeyad, A.M.; Murali, G.; Vatin, N.; Klyuev, S.; Ozbakkaloglu, T.; Vasilev, Y. Use of recycled concrete aggregates in production of green cement-based concrete composites: A review. Crystals 2021, 11, 232. [CrossRef]

2. Perry, S.H.; Bischoff, P.H.; Yamura, K. Mix details and material behaviour of polystyrene aggregate concrete. Mag. Concr. Res. 1991, 43. [CrossRef]

3. Amran, Y.H.M.; Alyousef, R.; Alabduljabbar, H.; El-Zeadani, M. Clean production and properties of geopolymer concrete: A review. J. Clean. Prod. 2020, 251, 119679. [CrossRef]

4. Banfill, P.G.H. Rheological methods for assessing the flow properties of mortar and related materials. Constr. Build. Mater. 1994, 8 , 43-50. [CrossRef]

5. Feys, D.; Khayat, K.H.; Khatib, R. How do concrete rheology, tribology, flow rate and pipe radius influence pumping pressure? Cem. Concr. Compos. 2016, 16, 38-46. [CrossRef]

6. Feys, D.; Khayat, K.H.; Perez-Schell, A.; Khatib, R. Prediction of pumping pressure by means of new tribometer for highlyworkable concrete. Cem. Concr. Compos. 2015, 57. [CrossRef]

7. Ferraris, C.F. Measurement of the rheological properties of high performance concrete: State of the art report. J. Res. Natl. Inst. Stand. Technol. 1999, 104, 461-478. [CrossRef]

8. Kong, X.; Zhang, Y.; Hou, S. Study on the rheological properties of Portland cement pastes with polycarboxylate superplasticizers. Rheol. Acta 2013, 52. [CrossRef]

9. Fediuk, R.S. Mechanical Activation of Construction Binder Materials by Various Mills. In Proceedings of the IOP Conference Series: Materials Science and Engineering, Yurga, Russia, 26-28 November 2016; Volume 125.

10. Chernysheva, N.V.; Lesovik, V.S.; Drebezgova, M.Y.; Shatalova, S.V.; Alaskhanov, A.H. Composite Gypsum Binders with Silica-containing Additives. In Proceedings of the IOP Conference Series: Materials Science and Engineering, Tomsk, Russia, 4-6 December 2018.

11. Bartos, P.J.M.; Sonebi, M.; Tamimi, A.K. Workability and Rheology of Fresh Concrete: Compendium of Tests; Report of RILEM Technical Committee TC 145-WSM, Workability of Special Concrete Mixes; Cachan Cedex: Paris, France, 2002.

12. Mosaberpanah, M.A.; Eren, O. Effect of Density on Compressive Strength of Ultra High Performance Fiber Reinforced Concrete (UHPFRC) Using Design of Experiment. Solid State Phenom. 2016. [CrossRef]

13. Chapman, C.M. Method and Apparatus for Determining Consistency; ASTM V13 Part II; ASTM International: West Conshohocken PA, USA, 1913; pp. 1045-1052.

14. Graf, O. Experiments of the behaviour of reinforcement in concrete of various compositions. Dtsch. Aussch. Eisenbeton 1933, 71, 36-60.

15. Tattersall, G. Workability and Quality Control of Concrete; E \& FN Spon: London, UK, 1991.

16. Tattersall, G.H.; Bloomer, S.J. Further development of the two-point test for workability and extension of its range. Mag. Concr. Res. 1979, 31, 202-210. [CrossRef]

17. Wallevik, J. Rheology of Particle Suspension. Ph.D. Thesis, University of Iceland, Reykjavik, Iceland, 2003.

18. Kavitha, S.M.; Venkatesan, G.; Avudaiappan, S.; Saavedra Flores, E. Mechanical and Flexural Performance of Self Compacting Concrete with Natural Fiber, Revista de la Construcción. J. Constr. 2020, 19, 370-380. [CrossRef]

19. Thamilselvi, P.; Siva, A.; Kabilan, N.; Prabu, K. Internal curing on high performance concrete with pre-soaked light weight aggregate to prevent shrinkage. J. Struct. Eng. 2017, 44, 414-421.

20. Siva, A.; Thamilselvi, P.; NishaDevi, A.; Ashvini, B. Experimental Investigation on Partial Replacement of Fine Aggregate Using Crushed Spent Fire Bricks. Am. J. Eng. Res. 2017, 6, 1-4.

21. Vijayprabha, C.; Brindha, D.; Siva, A. Durability performance of copper lag concrete admixed with polypropylene fibre. J. Struct. Eng. 2017, 43, 598-606.

22. Subramanian, K.B.; Siva, A.; Swaminathan, S.; Ajin, A.M.G. Development of high strength self-curing concrete using super absorbing polymer. WASET Int. J. Civ. Environ. Struct. Constr. Archit. Eng. 2015, 9, 1536-1541.

23. Fediuk, R.; Yushin, A. Composite binders for concrete with reduced permeability. In Proceedings of the IOP Conference Series: Materials Science and Engineering, Tomsk, Russia, 9-11 November 2015; Volume 116.

24. Chernysheva, N.; Lesovik, V.; Fediuk, R.; Vatin, N. Improvement of Performances of the Gypsum-Cement Fiber Reinforced Composite (GCFRC). Materials 2020, 3847. [CrossRef]

25. Haridharan, M.K.; Matheswaran, S.; Murali, G.; Abid, S.R.; Fediuk, R.; Mugahed Amran, Y.H.; Abdelgader, H.S. Impact response of two-layered grouted aggregate fibrous concrete composite under falling mass impact. Constr. Build. Mater. 2020. [CrossRef] 
26. Uzomaka, O.J. A concrete rheometer and its application to a rheological study of concrete mixes. Rheol. Acta 1974, 13, 21. [CrossRef]

27. Wallevik, O.H. The Rheology of Fresh Concrete and Its Application on Concrete with and without Silica Fume; The Norwegian University of Science and Technology: Trondheim, Norway, 1990.

28. Ling, G.; Shui, Z.; Sun, T.; Gao, X.; Wang, Y.; Sun, Y.; Wang, G.; Li, Z. Rheological Behavior and Microstructure Characteristics of SCC Incorporating Metakaolin and Silica Fume. Materials 2018, 11, 2576. [CrossRef]

29. Fediuk, R.; Mosaberpanah, M.A.; Lesovik, V. Development of fiber reinforced self-compacting concrete (FRSCC): Towards an efficient utilization of quaternary composite binders and fibers. Adv. Concr. Constr. 2020, 9, 387-395.

30. Fediuk, R.S.; Ibragimov, R.A.; Lesovik, V.S.; Akopian, A.K.; Teleshev, A.A.; Khankhabaev, L.R.; Ivanov, A.S. Application of cementitious composites in mechanical engineering. In Proceedings of the IOP Conference Series: Materials Science and Engineering, Tomsk, Russia, 4-6 December 2017; Volume 327.

31. Siddika, A.; Amin, M.R.; Rayhan, M.A.; Islam, M.S.; Al Mamun, M.A.; Alyousef, R.; Mugahed Amran, Y.H. Performance of sustainable green concrete incorporated with fly ash, rice husk ash, and stone dust. Acta Polytech. 2021, 61, 279-291. [CrossRef]

32. Amran, Y.H.M.; Soto, M.G.; Alyousef, R.; El-Zeadani, M.; Alabduljabbar, H.; Aune, V. Performance investigation of highproportion Saudi-fly-ash-based concrete. Results Eng. 2020. [CrossRef]

33. Zeyad, A.M.; Johari, M.A.M.; Alharbi, Y.R.; Abadel, A.A.; Amran, Y.H.M.; Tayeh, B.A.; Abutaleb, A. Influence of steam curing regimes on the properties of ultrafine POFA-based high-strength green concrete. J. Build. Eng. 2021, 38. [CrossRef]

34. Amran, M.; Murali, G.; Fediuk, R.; Vatin, N.; Vasilev, Y.; Abdelgader, H. Palm oil fuel ash-based eco-efficient concrete: A critical review of the short-term properties. Materials 2021, 14, 332. [CrossRef] [PubMed]

35. Mugahed Amran, Y.H. Determination of Structural Behavior of Precast Foamed Concrete Sandwich Panel; Universiti Putra Malaysia (UPM): Selangor, Malaysia, 2016.

36. Elistratkin, M.Y.; Lesovik, V.S.; Zagorodnjuk, L.H.; Pospelova, E.A.; Shatalova, S.V. New point of view on materials development. In Proceedings of the IOP Conference Series: Materials Science and Engineering, Tomsk, Russia, 4-6 December 2017.

37. Neville, A. Properties of Concrete; Addison We.; Pearson: London, UK, 1995.

38. Neville, A. Chairman's summary. In Fresh Concrete: Important Properties and their Measurement. In Proceedings of the RILEM Seminar, Leeds, UK, 22-24 March 1973.

39. Tiwari, A.K.; Dave, U.V.; Bansal, S. Rheological behavior of concrete with some supplementary cementations material. Indian Concr. J. 2018, 92, 11-18.

40. Amran, M.; Debbarma, S.; Ozbakkaloglu, T. Fly ash-based eco-friendly geopolymer concrete: A critical review of the long-term durability properties. Constr. Build. Mater. 2021. [CrossRef]

41. Amran, M.; Fediuk, R.; Murali, G.; Vatin, N.; Karelina, M.; Ozbakkaloglu, T.; Krishna, R.S.; Kumar, A.S.; Kumar, D.S.; Mishra, J. Rice husk ash-based concrete composites: A critical review of their properties and applications. Crystals 2021, 11, 168. [CrossRef]

42. Amran, M.; Murali, G.; Khalid, N.H.A.; Fediuk, R.; Ozbakkaloglu, T.; Lee, Y.H.; Haruna, S.; Lee, Y.Y. Slag uses in making an ecofriendly and sustainable concrete: A review. Constr. Build. Mater. 2021, 272. [CrossRef]

43. Volodchenko, A.A.; Lesovik, V.S.; Cherepanova, I.A.; Volodchenko, A.N.; Zagorodnjuk, L.H.; Elistratkin, M.Y. Peculiarities of non-autoclaved lime wall materials production using clays. In Proceedings of the IOP Conference Series: Materials Science and Engineering, Tomsk, Russia, 4-6 December 2017.

44. Feys, D.; Cepuritis, R.; Jacobsen, S.; Lesage, K.; Secrieru, E.; Yahia, A. Measuring Rheological Properties of Cement Pastes: Most common Techniques, Procedures and Challenges. RILEM Tech. Lett. 2017, 2, 29-35. [CrossRef]

45. Antonio Pereira de Oliveira, L. Rheology of self-compacting concrete mortar phase. In Proceedings of the International Conferences on Civil Engineering, Covilha, Portugal, 26-29 May 2013.

46. Kwan, A.K.H.; Li, L.G. Combined effects of water film thickness and paste film thickness on rheology of mortar. Mater. Struct. 2012, 45, 1359-1974. [CrossRef]

47. Haist, M.; Ferrara, L. Rheological characterization of high performance fiber reinforced cementitious composites. In Proceedings of the 8th RILEM International Symposium on Fibre Reinforced Concrete, Guimaraes, Portugal, 19-21 September 2012; pp. 66-74.

48. Amran, Y.H.M. Influence of structural parameters on the properties of fibred-foamed concrete. Innov. Infrastruct. Solut. 2020, 5 . [CrossRef]

49. Abid, S.R.; Murali, G.; Amran, M.; Vatin, N.; Fediuk, R.; Karelina, M. Evaluation of mode II fracture toughness of hybrid fibrous geopolymer composites. Materials 2021, 14, 349. [CrossRef]

50. Murali, G.; Amran, M.; Fediuk, R.; Vatin, N.; Raman, S.N.; Maithreyi, G.; Sumathi, A. Structural behavior of fibrous-ferrocement panel subjected to flexural and impact loads. Materials 2020, 13, 5648. [CrossRef]

51. Murali, G.; Abid, S.R.; Abdelgader, H.S.; Amran, Y.H.M.; Shekarchi, M.; Wilde, K. Repeated Projectile Impact Tests on MultiLayered Fibrous Cementitious Composites. Int. J. Civ. Eng. 2021. [CrossRef]

52. Jaishankar, P.; Murali, G.; Salaimanimagudam, M.P.; Amran, Y.H.M.; Fediuk, R.; Karthikeyan, K. Study of topology optimized hammerhead pier beam made with novel preplaced aggregate fibrous concrete. Period. Polytech. Civ. Eng. 2020, 65, 287-298. [CrossRef]

53. Murali, G.; Abid, S.R.; Karthikeyan, K.; Haridharan, M.K.; Amran, M.; Siva, A. Low-velocity impact response of novel prepacked expanded clay aggregate fibrous concrete produced with carbon nano tube, glass fiber mesh and steel fiber. Constr. Build. Mater. 2021, 284. [CrossRef] 
54. Salaimanimagudam, M.P.; Murali, G.; Vivek Vardhan, C.M.; Amran, M.; Vatin, N.; Fediuk, R.; Vasilev, Y. Impact response of preplaced aggregate fibrous concrete hammerhead pier beam designed with topology optimization. Crystals 2021, 11, 147. [CrossRef]

55. ASTM C348-21. Flexural strength of hydraulic-cement mortars. Am. Soc. Test. Mater. 2002, 4, 1-6.

56. Lesovik, V.; Chernysheva, N.; Fediuk, R.; Amran, M.; Murali, G.; de Azevedo, A.R.G. Optimization of fresh properties and durability of the green gypsum-cement paste. Constr. Build. Mater. 2021, 287. [CrossRef]

57. Deb, P.S.; Sarker, P.K.; Barbhuiya, S. Sorptivity and acid resistance of ambient-cured geopolymer mortars containing nano-silica. Cem. Concr. Compos. 2016. [CrossRef]

58. Sumathi, A.; Murali, G.; Gowdhaman, D.; Amran, M.; Fediuk, R.; Vatin, N.I.; Laxme, R.D.; Gowsika, T.S. Development of bacterium for crack healing and improving properties of concrete under wet-dry and full-wet curing. Sustainability 2020, 12, 10346. [CrossRef] 